\title{
The Common Law Powers of Federal Courts
}

\author{
Thomas W. Merrill†
}

Lawmaking by federal courts has been a matter of controversy since the early days of the Republic. ${ }^{1}$ In the last forty years, the debate has fallen into roughly two periods, with Roe v. Wade ${ }^{2}$ marking the dividing line. During what might be called the "legal process" era of the 1950's and 1960's, scholarly energy was focused on Erie Railroad v. Tompkins ${ }^{3}$ and what was then called the "new federal common law." "To be sure, important work on judicial re-

$\dagger$ Associate Professor of Law, Northwestern University. The author would like to thank Robert Bennett, Frank Easterbrook, Michael Perry, Richard Posner, and Martin Redish for their helpful comments on an earlier draft.

1 One early example was the debate in the late eighteenth and early nineteenth centuries over the legitimacy of a federal common law of crimes. See generally Presser, A Tale of Two Judges: Richard Peters, Samuel Chase, and the Broken Promise of Federalist Jurisprudence, 73 Nw. U.L. REv. 26, 46-72 (1978) (discussing the debate between the Federalists and the Republicans over the power of courts to create a federal common law of crimes).

2410 U.S. 113 (1973).

304 U.S. 64 (1938).

- See, e.g., Friendly, In Praise of Erie-And of the New Federal Common Law, 39 N.Y.U. L. REv. 383 (1964); Hart, The Relations Between State and Federal Law, 54 Colum. L. REV. 489 (1954); Mishkin, The Variousness of "Federal Law": Competence and Discretion in the Choice of National and State Rules for Decision, 105 U. PA. L. REv. 797 (1957); Note, The Federal Common Law, 82 HaRv. L. REv. 1512 (1969) [hereinafter cited as Note, Federal Common Law]; Note, The Competence of Federal Courts To Formulate Rules of Decision, 77 HaRv. L. REv. 1084 (1964) [hereinafter cited as Note, Federal Courts]; Comment, Rules of Decision in Nondiversity Suits, 69 YaLE L.J. 1428 (1960). 
view was also done in those years, ${ }^{5}$ particularly in the wake of the Supreme Court's dramatic decision in Brown v. Board of Education, ${ }^{6}$ which outlawed racial segregation in public schooling. On the whole, however, it is safe to say that the legal process era gave more attention to dissecting Erie and its implications for federalism than to reconciling Brown with our commitment to democratic principles. $^{7}$

The situation is quite different today. Federal judicial lawmaking still commands an important place on the academic agenda, but the focus of attention has turned almost exclusively to lawmaking through judicial review, and in particular to what is variously called "noninterpretive" or "nonoriginalist" judicial review ${ }^{8}$-decisions (like Brown and Roe) that rest on principles not specifically intended by the framers of the Constitution. ${ }^{9}$ Writing about federal common law has slowed to a mere trickle. ${ }^{10}$ Indeed, there is a tendency to dismiss questions about the legitimacy of federal common law as inconsequential. ${ }^{11}$

Despite the difference in the focuses of these two periods, they are alike in at least one respect. For both the legal-process school and modern constitutional theorists, federal common law and judicial review have been treated as presenting wholly separate issues. Generally speaking, federal common law has been perceived as raising issues of federalism and separation of powers; judicial review-especially nonoriginalist judicial review-has been perceived as raising questions about the limits of textual interpretation and our fidelity to democratic ideals.

- See, e.g., Alexander Bickel, The Least Dangerous Branch (1962); Wechsler, Toward Neutral Principles of Constitutional Law, 73 HaRv. L. REv. 1 (1959).

6 347 U.S. 483 (1954).

7 See Bruce Ackerman, Private Property and the Constitution 272 n.4 (1977); Westen \& Lehman, Is There Life for Erie After the Death of Diversity?, 78 Mich. L. REv. 311, 312 (1980) (Erie doctrine was "the central concern of an entire generation of academic lawyers").

${ }^{8}$ See, e.g., Brest, The Misconceived Quest for the Original Understanding, 60 B.U.L. REv. 204 (1980) ("nonoriginalist"); Grey, Do We Have an Unwritten Constitution?, 27 StaN. L. REv. 703 (1975) ("noninterpretive").

9 See, e.g., Raoul Berger, Government by Judiciary: The Transformation of the Fourteenth Amendment (1977); John Hart Ely, Democracy and Distrust (1980); Michael Perry, The Constitution, the Courts, and Human Rights (1982); Constitutional Adjudication and Democratic Theory, 56 N.Y.U. L. REv. 259 (1981); Judicial Review Versus Democracy, 42 Оніо ST. L.J. 1 (1981).

10 There are some exceptions. E.g., Guido Calabresi, A Common Law for the Age of Statutes ch. 9 (1982); Martin Redish, Federal Jurisdiction: Tensions in the Allocation of JUdicial Power ch. 4 (1980); Westen \& Lehman, supra note 7.

"See, e.g., J. Ely, supra note 9, at 4, 67-68; M. PerRy, supra note 9, at 28 n.*. 
In this article, I will attempt to break down the implicit barrier that exists in the commentary on these two forms of federal judicial lawmaking. My objective in doing so is twofold. First, I would like to inject into traditional thinking about federal common law some of the insights developed in the recent literature on nonoriginalist judicial review. Second, I would like to turn the analysis around and ask whether some of the questions that arise in the field of constitutional law-in particular the legitimacy of nonoriginalist judicial review-can profitably be analyzed as issues of federal common law.

I will begin with two preliminary matters involving the assumptions that underlie the analysis: in Part I, I define "federal common law," and, in Part II, I discuss the standard or norm I will apply in assessing the legitimacy of that body of law. In Part III, I will describe four general principles that combine to make up the content of the norm that I apply: the constitutional principles of federalism, separation of powers, and electoral accountability, and the statutory restrictions imposed by the Rules of Decision Act. These general principles suggest that federal common law is legitimate insofar as it is the product of textual interpretation, understood to mean a search for the specific intentions of the draftsmen of the text. In Part IV, I will advance two doctrines-which I term preemptive lawmaking and delegated lawmaking-that I believe are also consistent with this norm, but that reflect two different conceptions of textual interpretation. These two doctrines expand considerably the sphere in which federal common law may be considered legitimate; together with the conclusions reached in Part III, they can be used to express a general theory of federal common law. Finally, in Part V, I will review three areas in which the issue of lawmaking by federal courts has been particularly controversial: the judicial creation of implied rights of action, "constitutional common law,"12 and nonoriginalist judicial review. I will attempt to show how the general theory developed in Parts III and IV can help resolve these issues of legitimacy in a more coherent and conceptually satisfying manner than has thus far been achieved by either the Supreme Court or the academic commentators.

\section{The Definition of Federal Common Law}

The concept of federal common law is elusive, and there is

${ }^{12}$ The term is Henry Monaghan's. See Monaghan, The Supreme Court, 1974 Term-Foreword: Constitutional Common Law, 89 HARv. L. REv. 1, 3 (1975). 
considerable danger of assuming away important questions at the definitional stage. For example, many courts have tied the notion of federal common law to an implicit conception of the limits of textual interpretation. In this view, federal common law begins where textual interpretation-or what courts conventionally regard as "interpretation"-ends. Thus, in two recent decisions concerning rights of contribution among defendants, the Supreme Court drew a sharp distinction between the creation of such a right as an "implied right of action" and the creation of such a right as a matter of "federal common law." 13 The distinction appears to rest on the belief that implied rights of action require a finding of a specific congressional intent to create such an action, ${ }^{14}$ whereas such a finding plays no role in the creation of federal common law. In other words, a court that creates an implied right of action is "interpreting" a federal text-uncovering a specific legislative intent-but a court that fashions federal common law is not "interpreting" a text in this sense. ${ }^{15}$

Academic commentators have also recognized a relationship between textual interpretation and federal common law, but they have not generally drawn such a sharp distinction between the two. As one recent article puts it:

The difference between "common law" and "statutory interpretation" is a difference in emphasis rather than a difference in kind. The more definite and explicit the prevailing legislative policy, the more likely a court will describe its lawmaking as statutory interpretation; the less precise and less explicit the perceived legislative policy, the more likely a court will speak of common law. The distinction, however, is

${ }_{13}$ Northwest Airlines v. Transport Workers Union, 451 U.S. 77, 86 (1981) (describing federal common law and implied rights of action as "two quite different theories"); Texas Indus. v. Radcliff Materials, Inc., 451 U.S. 630, 638 (1981) (similar).

14 Transamerica Mortgage Advisors v. Lewis, 444 U.S. 11, 15-16 (1979); Touche Ross \& Co. v. Redington, 442 U.S. 560, 568 (1979).

15 I will sometimes speak of the search for specific intentions as "conventional interpretation." This is roughly synonymous with what constitutional theorists call "originalism" or "interpretivism," although the search for specific intentions is also suggestive of what is only implicit in the notion of originalism or interpretivism - that one looks for specific answers provided by the enacting body to the interpretive question at issue, rather than for the broad "purposes" or "values" embraced by that body. For general discussions of conventional interpretation in the narrow sense of the search for specific intentions, see Munzer \& Nickel, Does the Constitution Mean What It Always Meant?, 77 Colum. L. Rev. 1029, 1030 33 (1977); Schauer, An Essay on Constitutional Language, 29 UCLA L. Rev. 797, 804-12 (1982). For a different notion of interpretation as the search for broad "concepts" intended by the enacting body, see Dworkin, The Forum of Principle, 56 N.Y.U. L. REv. 469 passim (1981). 
entirely one of degree. ${ }^{16}$

In this view, federal common law is not qualitatively different from textual interpretation, but rather is an extension of it, with "interpretation" now understood in a broader sense than the search for the specific intentions of the draftsmen. ${ }^{17}$

Both of these views, however, rest on unexamined assumptions about what can be legitimately described as textual interpretation. The judicial view-at least that reflected in the recent casespresupposes that interpretation means searching for and enforcing the specific intentions of the enacting body. The academic view-at least that reflected in the work from which the above quotation is taken-assumes that interpretation also includes filling in textual "gaps" in accordance with the court's conception of "political morality."18

This conflict surrounding the appropriate nature and scope of textual interpretation is too important to resolve as a matter of definition. Consequently, I will define federal common law to include all potentially controversial forms of textual interpretation. "Federal common law," as I use the term, means any federal rule of decision that is not mandated on the face of some authoritative federal text-whether or not that rule can be described as the product of "interpretation" in either a conventional or an unconventional sense. ${ }^{19}$

Another distinction sometimes asserted at the level of definition is that federal common law is somehow different or distinct from constitutional law. To a large extent, this assumption is simply a variation on the first: constitutional lawmaking by federal courts is thought to rest on textual interpretation-in this case interpretation of the Constitution-whereas federal common law is not. But, as innumerable scholars have pointed out in recent years, most of what we consider constitutional law does not rest on "in-

16 Westen \& Lehman, supra note 7, at 332.

17 See P. Bator, P. Mishinin, D. Shapiro \& H. Wechsler, Hart and Wechsler's The Federal Courts and the Federal System 770 (2d ed. 1973) (textual interpretation "shades into" judicial lawmaking) [hereinafter cited as Hart \& WECHSLER].

18 Westen \& Lehman, supra note 7, at 336; cf. Dworkin, Political Judges and the Rule of Law, 64 Proc. Brit. Academy 259, 267 (1978) (judges should decide hard cases on the basis of moral principles not inconsistent with prior law).

10 This is close, but not identical, to the definition of federal common law offered by Hart and Wechsler: "rules of decision where the authority for a federal rule is not explicitly or clearly found in federal statutory or constitutional command." HART \& WECHSLER, supra note 17 , at 770 . Hart and Wechsler, however, speak of the authority for the rule not being explicitly set forth in a federal textual command; I define federal common law more broadly, as arising where the rule itself is not explicitly set forth in a textual command. 
terpretation" of the Constitution, at least in the conventional sense of searching for the specific intentions of the framers of that document. ${ }^{20}$ Rather, it is noninterpretive or nonoriginalist. ${ }^{21}$ In its relationship to the text, therefore, most modern constitutional law is indistinguishable from what courts call federal common law.

Another commonly asserted basis for distinguishing between federal common law and constitutional law is that the former can be overturned by Congress, ${ }^{22}$ whereas the latter can be reversed only by a constitutional amendment. This distinction, however, suggests at most that constitutional lawmaking may be more objectionable than what courts tend to call federal common law. It does not necessarily support the conclusion that the general constraints that limit the power of federal courts to make federal common law differ from those that apply when they engage in constitutional lawmaking. Thus, the fact that constitutional lawmakingincluding nonoriginalist judicial review-is immune from congressional override may justify us in regarding it as an especially troubling form of judicial lawmaking, but this fact does not support the claim that it is a different type of judicial lawmaking altogether.

As with attempts to distinguish textual interpretation from federal common law, differentiating constitutional law from federal common law at the definitional stage begs some important questions. I will therefore include within the compass of federal common law all federal rules of decision not mandated on the face of a federal text-that is, a federal statute or treaty or the Constitution. It follows that federal common law, as I use the term, will include decisions that are not required by the language of the Constitution, but that nevertheless are treated as having the status of constitutional law and may thus be overridden only by constitutional amendment.

One final comment is in order concerning the definition of federal common law. Federal common law, as its name suggests, is federal law. Consequently, the Supreme Court is the final arbiter of its content, and the resulting rules are binding on state courts under the supremacy clause of the Constitution. ${ }^{23}$ This serves to

${ }^{20}$ See, e.g., M. Perry, supra note 9, at 10-11; Sandalow, Constitutional Interpretation,

79 Mich. L. REv. 1033, 1035 (1981); Grey, supra note 8, at 710-14.

${ }^{21}$ See supra note 8 and accompanying text.

22 See Monaghan, supra note 12 , at 11 .

${ }^{23}$ U.S. Const. art. VI, cl. 2; see Hill, The Law-Making Power of the Federal Courts: Constitutional Preemption, 67 Colum. L. Rev. 1024, 1073-79 (1967) (federal judge-made law binding on states via supremacy clause). 
distinguish federal common law from the "general" common law developed by federal courts under the regime of Swift $v$. Tyson, ${ }^{24}$ which was binding on federal courts but not on state courts. It also serves to distinguish federal common law from what a federal court does in a diversity case or any other case where state law provides the rule of decision. Even though a federal court in such a case may "make law" by declaring a rule when state law is silent or unsettled, ${ }^{25}$ the rule is not binding on state courts and hence is not federal common law.

In short, federal common law, as I define it, refers to legal rules (substantive or procedural) that (1) are propounded by courts, ${ }^{26}$ that is, are not found on the face of an authoritative federal text, and (2) have the status of federal law. This definition renders the universe of federal common law extremely broad. It includes not only rules that are universally regarded as federal common law (such as the federal common law of international relations ${ }^{27}$ or the federal common law of nuisance ${ }^{28}$ ) but also rules that are only occasionally considered federal common law (such as implied rights of action ${ }^{29}$ ) and rules that are almost never treated as federal common law (such as "ordinary" statutory construction and nonoriginalist judicial review). The hypothesis I propose to test is that these seemingly disparate issues have more in common than meets the eye and that they can profitably be treated as variants of the general phenomenon of federal judicial lawmaking.

\section{The Internal Norm of Legitimacy}

The Supreme Court recently declared that "[f]ederal courts,

2441 U.S. (16 Pet.) 1 (1842), overruled, Erie R.R. v. Tompkins, 304 U.S. 64 (1938).

${ }^{25}$ See, e.g., Meredith v. Winter Haven, 320 U.S. 228, 237 (1943) (Erie did not free federal courts in diversity cases from duty to decide even unsettled questions of state law).

${ }^{26}$ While federal courts are undeniably the principal actors in the formation of federal common law, state courts may also entertain claims grounded in federal law, and in so doing may be called upon to "make" federal law. Thus, I have framed the definition in terms of "courts" rather than "federal courts." Because state courts play a rather minor role in formulating judge-made federal law, however, and because state-court-created federal law is subject to revision by the Supreme Court, see, e.g., 28 U.S.C. § 1257 (1982) (Supreme Court given jurisdiction over appeals from state courts where state court has held federal treaty or statute invalid); Martin v. Hunter's Lessee, 14 U.S. (1 Wheat.) 304, 338-43 (1816) (upholding power of Supreme Court to review state-court decisions involving constitutional questions), I will generally restrict my discussion to lawmaking by federal courts.

${ }^{27}$ Banco Nacional de Cuba v. Sabbatino, 376 U.S. 398, 423-27 (1964).

${ }^{28}$ Illinois v. City of Milwaukee, 406 U.S. 91, 103 (1972).

28 See Comment, Implied Causes of Action: A Product of Statutory Construction or the Federal Common Law Power?, 51 U. CoLo. L. Rev. 355, 369-70 (1980) (suggesting analysis of implied causes of action under a federal common law approach). 
unlike state courts, are not general common-law courts and do not possess a general power to develop and apply their own rules of decision." ${ }^{30}$ Almost simultaneously, however, the Court recognized "the need and authority in some limited areas to formulate what has come to be known as 'federal common law." "31 Pronouncements to the effect that the common law powers of federal courts are limited or restricted, but that they nevertheless exist in certain circumstances, clearly presuppose some standard or norm for distinguishing legitimate from illegitimate exercises in judicial lawmaking.

In order to determine the legitimate lawmaking powers of federal courts, I will apply a norm of legitimacy drawn from positive law: the existing set of legal principles that participants in our legal system consider binding and authoritative. Because this norm of legitimacy is drawn from principles of positive law within the structure of our system of government and does not draw its force from any "higher-order" or "natural" law, I call it an "internal" norm. The fundamental elements of this internal norm are structural principles, embodied in the federal Constitution, that allocate lawmaking powers among the branches of government. ${ }^{32}$ Following more-or-less conventional terminology, I will refer to these principles as "federalism," "separation of powers," and "electoral accountability." In addition to these constitutional principles, I will also consider a statutory constraint-the Rules of Decision Act-that I view as essentially derived from these constitutional principles.

Obviously, the precise meaning of these basic structural principles is not self-evident; they must themselves be interpreted and given more precise content before they can be used to define the permissible scope of federal common law. For the purposes of the present discussion, these internal principles will be defined as they are currently understood by the Supreme Court. ${ }^{33}$ I will not make

${ }^{30}$ City of Milwaukee v. Illinois, 451 U.S. 304, 312 (1981).

31 Texas Indus. v. Radcliff Materials, Inc., 451 U.S. 630, 640 (1981).

32 The internal norm that I will describe does not provide a complete account of the principles that limit the actions of federal judges. A complete account would have to include general jurisprudential constraints, such as the obligation to follow precedent and to frame decisions in terms of "neutral principles." It would also have to take into account those constraints derived from article III, such as the standing, mootness, and ripeness doctrines, which relate more to the occasions on which federal judicial power may be exercised than to the nature and extent of that power once an appropriate occasion for its exercise is presented.

${ }^{33}$ Of course, there can also be conflicting "interpretations" of the Supreme Court's interpretation of these general principles. This problem is particularly acute in the present 
any systematic effort to determine their "original" meaning, nor will I try to articulate a general theory of their "true" or "correct" meaning. ${ }^{34}$ Thus, I will take the internal norm of legitimacy to be composed of constitutionally based structural principles, as currently interpreted by the Supreme Court, that define or limit the lawmaking powers of the federal courts.

On its face, invocation of this norm of legitimacy might seem wholly unremarkable. The Constitution is the ultimate source of national authority in our political system. ${ }^{35}$ Moreover, structural principles of federalism, separation of powers, and electoral accountability are widely regarded as important constituents of that Constitution. ${ }^{36}$ Finally, the Supreme Court is today regarded, both by self-proclamation ${ }^{37}$ and general agreement, ${ }^{38}$ as the authoritative expositor of the meaning of the constitutional scheme. Thus, it should not be surprising that an internal norm of legitimacy-or at least something like it-is the norm that has been conventionally applied in the literature on Erie Railroad v. Tompkins and federal common law. ${ }^{39}$

context because the Court rarely discusses at any length the implications for judicial lawmaking of the principles of federalism, separation of powers, or electoral accountability. I will not explore this problem at any length here, however, in part because there is relatively little current controversy over the proper techniques for interpreting a body of judicial precedent, at least in comparison with the current controversy over the proper approach to interpreting statutes or the Constitution. The constitutional theorists who stress the difficulty of understanding the meaning of the constitutional text generally do not suggest that there are similar difficulties in understanding Supreme Court opinions that explicate the text. Cf. Easterbrook, Statutes' Domains, 50 U. CHI. L. REv. 533, 534 n.2 (1983) ("If statutes' words do not convey meaning and bind judges, why should judges' words bind or even interest the rest of us?").

${ }^{34}$ An internal norm is a powerful tool because it rests on principles that we currently recognize as legitimate. This sort of norm is therefore less controversial than an external norm based on standards of moral truth or natural law that must first be accepted before they can be used to answer the question of legitimacy. I take it that there is substantial agreement in our society that constitutional principles articulated by the Supreme Court are law. A norm derived from these principles ought to be more acceptable than a norm derived from principles or propositions that are outside the law.

${ }^{35}$ See, e.g., Monaghan, Our Perfect Constitution, 56 N.Y.U. L. Rev. 353, 384 (1981); Dworkin, supra note 15 , at 475 .

${ }^{36}$ See, e.g., Younger v. Harris, 401 U.S. 37, 44 (1971) (federalism); INS v. Chadha, 103 S. Ct. 2764, 2781-82 (1983) (separation of powers); Chevron, U.S.A., Inc. v. Natural Resources Defense Council, Inc., 104 S. Ct. 2778, 2793 (1984) (electoral accountability).

${ }_{37}$ See, e.g., INS v. Chadha, 103 S. Ct. 2764, 2779 (1983); Cooper v. Aaron, 358 U.S. 1, 18 (1958).

${ }^{38}$ See Monaghan, supra note 12, at 1-2.

${ }^{39}$ See authorities cited supra note 4. For more recent invocations of structural principles as a basic norm, see R. Bridwell \& R. Whitten, The Constitution and the Common Law 2, 29 (1977); Schrock \& Welsh, Reconsidering the Constitutional Common Law, 91 Harv. L. Rev. 1117, 1127-31 (1978); Comment, supra note 29, at 374-80. 
Nevertheless, despite the apparent orthodoxy of this norm, it is widely asserted by contemporary constitutional theorists that structural principles reflected in the Constitution cannot serve as a starting point in a discussion of the legitimacy of federal judicial lawmaking. On the contrary, it is said, some sort of "preconstitutional" norm ${ }^{40}$ is required because the text of the Constitution does not itself explain how that text is to be construed. ${ }^{41}$

Unquestionably, a theory of interpretation is crucial to any account of the legitimate scope of federal common law. But this does not mean, as many constitutional theorists seem to think, that the first premise in any account of federal judicial lawmaking must be a theory of interpretation. I will begin not with a theory of interpretation but with the Supreme Court's conception of the legitimate allocation of lawmaking power among federal courts and other branches of government. ${ }^{42}$ In other words, I propose to develop a theory of interpretation from a particular conception of the Constitution, rather than to develop a particular conception of the Constitution from a theory of interpretation.

One reason why the proposed strategy is attractive is that no consensus has emerged among constitutional theorists about the appropriate "preconstitutional" theory of interpretation. ${ }^{43}$ It is more likely that a reasonable consensus can be reached about the content of an internal norm grounded in positive law and that useful discussion can thus be promoted.

Two final comments are in order about the content of the norm. First, there is no circularity involved in using decisions of the Supreme Court to assess the legitimacy of decisions of the Supreme Court-at least if we can distinguish intelligibly between

${ }^{40}$ This point is noted in, and I have borrowed the term from, Kay, Preconstitutional Rules, 42 Oнго ST. L.J. 187 (1981).

${ }^{11}$ See, e.g., Levinson, Law as Literature, 60 Tex. L. Rev. 373 passim (1982); Tushnet, Following the Rules Laid Down: A Critique of Interpretivism and Neutral Principles, 96 HARv. L. Rev. 781, 786-804 (1983).

${ }^{42}$ My colleague Michael Perry has argued that invocation of the norms of federalism and separation of powers "is predicated on the originalist conception of the text." Perry, The Authority of Text, Tradition, and Reason: A Theory of Constitutional "Interpretation," So. CAL. L. REv. (forthcoming). This argument overlooks the possibility that the Supreme Court's current understanding of federalism and separation of powers can give rise to an internal norm of legitimacy and that originalism can be deduced from that norm.

${ }^{43}$ See Richards, Moral Philosophy and the Search for Fundamental Values in Constitutional Law, 42 Онго Sт. L.J. 319 (1981) (suggesting that the Constitution be interpreted through moral reasoning); Levinson, supra note 41 (suggesting that the Constitution be interpreted according to the canons of new literary criticism); Perry, supra note 42 (suggesting that the Constitution be interpreted as a (non-fundamentalist) theologian would construe a sacred religious text). 
the Court's explication of general structural principles and its application of those principles in particular cases. The norm of legitimacy is defined by those decisions that are concerned with the allocation of lawmaking powers among different branches of government; it is not derived from all cases recognizing some form of federal common law. What we are looking for, in other words, are leading decisions or lines of decisions that define structural principles "intended to maintain a rough system of power allocation over long periods of time." 4

Second, there is no logical difficulty involved in applying a constitutionally based norm of legitimacy to decisions that purport to derive their authority from broad constitutional principlessuch as cases decided under a nonoriginalist approach to judicial review. Indeed, as a logical matter, the question of the power of federal courts to make law should precede questions about the content of that law. ${ }^{45}$ Thus, when federal courts are called upon to enforce a constitutional provision that does not itself allocate lawmaking powers among the branches of government, ${ }^{46}$ it is appropriate that they turn to general structural principles in the Constitution for an answer to the question, "What kind of judicial lawmaking is permissible in giving effect to this provision?"47 This is what courts have traditionally done when presented with what are conventionally regarded as questions of federal common law,

4 Nagel, Federalism as a Fundamental Value: National League of Cities in Perspective, 1981 Sup. CT. Rev. 81, 108.

${ }_{45}$ This is implicit in Marbury v. Madison, 5 U.S. (1 Cranch) 137 (1803), and in the role that this case plays in discourse about constitutional adjudication.

${ }^{46}$ I leave aside the question whether the internal norm can be applied, without hopeless circularity, in cases involving the interpretation of the basic structural principles that make up the content of the norm itself. This is an important question, but it is one that I shall make no attempt to answer here. Suffice it to say that we can start with the internal norm and use it to resolve a great many issues involving the legitimacy of federal common law, including most of the issues traditionally associated with federal common law and nonoriginalist judicial review.

${ }^{47}$ An analogy is suggested by section 5 of the fourteenth amendment, which authorizes Congress to enforce the provisions of that amendment "by appropriate legislation." The fourteenth amendment does not say what it means by "appropriate legislation." Presumably, then, in determining what Congress must do to enact legislation enforcing the amendment, one would look first to the general provisions of article I that spell out how Congress passes a law, and second to the rest of the amendment itself to see what laws would be "appropriate." Similarly, in determining what a federal court may do in giving effect to the fourteenth amendment (enforcement by federal courts not even being specifically mentioned in the amendment), one should look first to the general structural provisions that define the lawmaking powers of federal courts before determining what sort of decisional rules are permissible. 
and (as I discussed earlier ${ }^{48}$ ) there is no reason in principle why nonoriginalist judicial review cannot be regarded as a form of federal common law.

I admit that there is nothing inevitable about subjecting nonoriginalist judicial review (which derives from constitutional principles) to general structural principles defining the power of federal courts (which also derive from the Constitution). Since the Supreme Court has the last word in interpreting the meaning of the Constitution, it is conceivable that the Court could interpret each constitutional provision as a separate grant of lawmaking authority to federal courts, superseding the general structural principles that would otherwise apply. This might especially be true of the Bill of Rights. In this view, the Constitution would in effect reflect at least two internal norms of legitimacy-one (based on general structural principles) for nonconstitutional cases, and another (based on separate and essentially unrestricted grants of judicial power) for cases arising under provisions such as those of the Bill of Rights. Although, as a matter of original interpretation, I do not find this latter view particularly appealing or persuasive, it would have to be accepted-from the perspective of the internal norm-if the Court has in fact adopted it. In what follows, however, I will provisionally assume that a single norm of legitimacy applies to all forms of federal common law, whether or not such law purports to derive its authority directly from the Constitution. After we have considered the content of the internal norm of legitimacy and have seen how it would apply to judicial lawmaking under the Constitution, we will be in a better position to reconsider this assumption. We can then ask which of the two conceptions of federal judicial lawmaking-the "one norm" model or the "two norms" (or "many norms") model-has in fact been adopted (if only implicitly) by the Supreme Court. ${ }^{49}$

\section{Four Principles Limiting the Lawmaking Powers of FEderal Courts}

Three general constitutional principles-federalism, separation of powers, and electoral accountability-together with the Rules of Decision Act, can be said to allocate lawmaking powers among the federal courts and other branches of government. Although each of these four elements has been recognized as impor-

48 See supra notes $19-21$ and accompanying text.

48 See infra notes $296-99$ and accompanying text. 
tant in the literature on federal common law and judicial review, they are rarely if ever studied together as reflecting a single norm of legitimacy. ${ }^{50}$ I will consider each in turn, noting some of the ways in which they are interrelated.

\section{A. Federalism}

The first general ground for objecting to lawmaking by federal courts is based on the Constitution's division of governmental powers between the federal government and the states. Historically, the federalism principle has enjoyed a certain degree of prominence; indeed, it was the key principle invoked in Erie Railroad $v$. Tompkins, ${ }^{\mathbf{5 1}}$ the Supreme Court's cornerstone decision concerning the common law powers of federal courts. Today, the federalism principle continues to serve as a limitation on lawmaking by federal courts, but for reasons that are considerably more refined than those set forth in Erie.

As the general structure of the Constitution and the tenth amendment ${ }^{52}$ make clear, the framers anticipated that the federal government would exercise only specifically enumerated powers. All other powers were reserved to the states or the people. The federal judiciary, as a branch of the federal government, is also limited by this specific enumeration of powers. ${ }^{53}$ Thus, any asser-

so Authorities that would have to be counted as at least partial exceptions to this generalization are Monaghan, supra note 12, at 34-38 (federalism and separation of powers); Schrock \& Welsh, supra note 39, at 1127-31 (same); Westen \& Lehman, supra note 7, at 315-24 (Rules of Decision Act and federalism).

${ }^{51} 304$ U.S. 64 (1938). For a good analysis of the federalism principle underlying Erie and of various objections leveled against the Court's reliance on that principle, see Friendly, supra note 4 , at $392-98$.

${ }^{52}$ U.S. ConsT. amend. X ("The powers not delegated to the United States by the Constitution, nor prohibited by it to the States, are reserved to the States respectively, or to the people.").

${ }^{53}$ One possible objection to Erie's federalism analysis is that the Court merely asserted that the powers of federal courts are no greater than those of Congress. The framers, as students of the English common law tradition, were aware that there is a body of law applied by courts that has no direct source in legislative enactments. Therefore, it is at least plausible to suppose that the framers intended the newly formed federal judiciary to participate in the explication and development of such a body of law. See 1 William Crosskey, Politics and the Constitution in the History of the United States 622-25 (1953). Moreover, there are possible textual bases for ascribing common law powers to federal courts. Article III speaks of the "judicial power" of the United States but does not define what that means. The framers may have understood the "judicial power" to include the power, to be exercised concurrently with the state courts, to explicate rules of decision in the common law tradition. Alternatively, one could argue, along with Professor Crosskey, that the "Laws of the United States" referred to in article III include not only federal statutes but also the general common law received from England. Id. at 622 . This objection is persuasive, how- 
tion by the judiciary of a general power to make law would encroach upon the powers reserved to the states.

This, in a nutshell, is the constitutional thesis of Erie. The issue there was the legitimacy of the federal-court practice, sanctioned by Swift $v$. Tyson, ${ }^{54}$ of fashioning "general" common law rules of decision in diversity cases without regard to the decisions of state courts. Speaking for the Court, Justice Brandeis stated that "the course pursued" under Swift was unconstitutional:

Congress has no power to declare substantive rules of common law applicable in a State whether they be local in their nature or "general," be they commercial law or a part of the law of torts. And no clause in the Constitution purports to confer such a power upon the federal courts. ${ }^{55}$

Since the limitations imposed by the Constitution on the powers of the federal government are transgressed when federal courts promulgate "general" common law rules that are not binding on the states, it would seem to follow, a fortiori, that federal courts do not have inherent power to promulgate federal common law rules that do bind the states. ${ }^{56}$

The federalism analysis of Erie is subject to the powerful objection that the structure of government presupposed by Justice Brandeis's opinion no longer exists in any recognizable form. Although the framers may have intended that the federal government would be a government of limited powers, ${ }^{57}$ in the years since Erie the Supreme Court has permitted those powers to expand so much that today the federal government has authority to regulate

ever, only if we fudge about what kind of "common law" we mean. It is one thing to suppose that the framers intended federal courts to have the power to explicate the "general" common law (to assert, in other words, that Swift was closer to the original understanding than Erie). It is quite another, however, to maintain that federal courts were intended to have the power to fashion a body of federal common law binding upon the states. See infra note 56. This much bolder proposition would be inconsistent with the framers' commitment to separation of powers and the delegation of the federal lawmaking function to Congress. See infra notes 75-100 and accompanying text. In any event, the objection is irrelevant here, since Erie's federalism analysis is now part of the generally accepted norm of legitimacy.

5441 U.S. (16 Pet.) 1 (1842), overruled, Erie R.R. v. Tompkins, 304 U.S. 64 (1938).

ss Erie, 304 U.S. at 78.

${ }^{56}$ Indeed, it can be argued that the Supreme Court has never embraced the strong proposition that federal courts have inherent powers to make federal common law. See Wheaton v. Peters, 33 U.S. (8 Pet.) 591, 657 (1834) ("It is clear, there can be no common law of the United States.”); United States v. Hudson \& Goodwin, 11 U.S. (7 Cranch) 32 (1812) (no federal common law of crimes).

${ }^{57}$ See, e.g., The Federalist No. 45 (J. Madison); Scheiber, Federalism and the Constitution: The Original Understanding, in American Law and the Constitutional Order 85, 89-96 (L. Friedman \& H. Scheiber eds. 1978). 
in virtually any area it chooses. ${ }^{58}$ In recent years, the only check on this expansion pertained to activity integrally related to state governmental operations ${ }^{58}$ - and even this check has now been removed. ${ }^{60}$ The Court's acquiescence in the transformation of the federal government from one of limited powers to one of plenary authority might be illustrated with the facts of Erie itself. ${ }^{61}$ The issue there-the standard of care that a railroad owes to a pedestrian walking on a railroad right of way-is one that Congress today could clearly resolve by legislation enacted pursuant to its power to regulate interstate commerce. Since the issue therefore falls within the enumerated powers of the federal government (now viewed as plenary rather than limited), there would seem to be no reason for objecting on grounds of federalism if a federal court decided to formulate a rule of decision governing the issue.

The answer to this objection is that the federalism principle identified by Erie still exists but has been silently transformed from a general constraint on the powers of the federal government into an attenuated constraint that applies principally to one branch of that government-the federal judiciary. This can be demonstrated by tracing the development of the federalism principle in the years since Erie was decided. With respect to congressional power, judicially mandated restraints in the name of federalism have all but disappeared. ${ }^{62}$ With respect to judicial power, however, the federalism principle still has force. This can be seen, not only in cases concerned with substantive federal common law, ${ }^{63}$ but even more strikingly in a multitude of decisions dealing with

s8 See Monaghan, The Burger Court and "Our Federalism," Law \& Contemp. Probs., Summer 1980, at 39, 42; see generally EEOC v. Wyoming, $103 \mathrm{~S}$. Ct. 1054, 1064-68 (1983) (Stevens, J., concurring) (discussing the growth of federal power under the commerce clause).

${ }^{80}$ See National League of Cities v. Usery, 426 U.S. 833, 855 (1976), overruled, Garcia v. San Antonio Metro. Transit Auth., 105 S. Ct. 1005 (1985).

${ }^{60}$ Garcia v. San Antonio Metro. Transit Auth., 105 S. Ct. 1005 (1985). Even prior to Garcia, the Court repeatedly distinguished National League of Cities. See EEOC v. Wyoming, 460 U.S. 226, 236-42 (1983); FERC v. Mississippi, 456 U.S. 742, 758-70 (1982); Hodel v. Virginia Surface Mining \& Reclamation Ass'n, 452 U.S. 264, 289-93 (1981).

${ }^{61}$ See Mishkin, Some Further Last Words on Erie-The Thread, 87 Harv. L. Rev. 1682, 1684 n.10 (1974) ("reasonably clear" that, under the commerce clause, Congress could have legislated a rule that would have covered the facts of Erie).

${ }^{62}$ See supra note 58 and accompanying text.

${ }^{63}$ Most prominent in this connection are cases that continue to follow Erie in the context of diversity jurisdiction. See, e.g., Walker v. Armco Steel Corp., 446 U.S. 740 (1980); Ragan v. Merchants Transfer \& Warehouse Co., 337 U.S. 530 (1949). Even in non-diversity cases, however, the Court has invoked federalism concerns as a limitation on the scope of federal common law. See, e.g., Oregon ex rel. State Land Bd. v. Corvallis Sand \& Gravel Co., 429 U.S. 363, 378 (1977); Davies Warehouse Co. v. Bowles, 321 U.S. 144, 155 (1944). 
the general allocation of decisionmaking power between federal and state courts. ${ }^{64}$ Thus, while federalism, at least as it was understood in Erie, may be "dead," eralism" lives on. ${ }^{66}$

The theory that supports this transformation of the federalism principle was first articulated by Professor Herbert Wechsler ${ }^{67}$ and has recently been endorsed by the Supreme Court in Garcia v. San Antonio Metropolitan Transit Authority ${ }^{68}$ According to this theory, there is little need for federal courts to police congressional legislation in order to prevent intrusions into the traditional domain of the states because the states are represented in Congress and can block expansionist initiatives that would undermine their vital interests. Hence "the Court is on weakest ground when it opposes its interpretation of the Constitution to that of Congress in the interest of the states, whose representatives control the legislative process and, by hypothesis, have broadly acquiesced in sanctioning the challenged Act of Congress." 69 At the same time, however, the Supreme Court has also recognized that "the States are represented in Congress but not in the federal courts . . . ."70 By

64 See, e.g., Rizzo v. Goode, 423 U.S. 362, 379 (1976); Doran v. Salem Inn, Inc., 422 U.S. 922, 928 (1975); Younger v. Harris, 401 U.S. 37, 44 (1971); Railroad Comm'n v. Pullman Co., 312 U.S. 496, 500-01 (1941).

${ }^{6 s}$ Philip Kurland, Politics, the Constitution, and the Warren Court 96 (1970).

${ }^{6}$ See Maltz, Federalism and the Fourteenth Amendment: A Comment on Democracy and Distrust, 42 Oнго ST. L.J. 209, 215 n.27 (1981) (vast expansion of congressional power in the twentieth century does not foreclose "important problems of federalism" posed by expansion of Supreme Court's lawmaking power). I have borrowed the term "judicial federalism" from Laurence Tribe, American Constitutional Law § 3-39 (1978), and Weinberg, The New Judicial Federalism, 29 Stan. L. Rev. 1191, 1194-95 (1977).

67 Wechsler, The Political Safeguards of Federalism: The Rôle of the States in the Composition and Selection of the National Government, 54 ColuM. L. REv. 543 (1954). For a more elaborate presentation of Wechsler's hypothesis, see JESSE CHOPER, Judicial REview and the National Political Process 176-93 (1980); see also M. Perry, supra note 9, ch. 2 (accepting Professor Wechsler's theory as substantially correct).

${ }_{68} 105$ S. Ct. 1005 (1985).

${ }^{69}$ Wechsler, supra note 67, at 559 (footnote omitted). My recapitulation of the Wechsler-Garcia thesis should not be taken as an endorsement. Although the Court is clearly committed to this thesis through its deeds (and, now, its words), requiring that the thesis be regarded as an integral part of the internal norm, there are substantial grounds for questioning whether it makes sense, given the realities of our modern political culture. See Garcia v. San Antonio Metro. Transit Auth., 105 S. Ct. 1005, 1025 n.9 (1985) (Powell, J., dissenting) (adoption of the seventeenth amendment (providing for direct popular election of senators), weakening of local political parties, and national media coverage "have made Congress increasingly less representative of state and local interests"); Kaden, Politics, Money, and State Sovereignty: The Judicial Role, 79 Colum. L. REv. 847, 860-68 (1979) (describing changes in structural and political factors reducing congressional opposition to intrusions on the state governmental process).

${ }^{70}$ City of Milwaukee v. Illinois, 451 U.S. 304, 317 n.9 (1981). 
its own logic, therefore, the Wechsler-Garcia thesis applies only to congressional (and perhaps, though less forcefully, to presidential) initiatives undertaken at the expense of the states. It does not apply to such initiatives undertaken by an unelected federal judiciary. Consequently, the "political safeguards" that have been invoked to rationalize the elimination of constraints on congressional power do not justify abolition of all constraints on judicial power. ${ }^{71}$

What are the legitimate powers of federal courts under the Wechsler-Garcia version of judicial federalism? The thesis suggests that federal courts should relentlessly enforce constitutional provisions and congressional enactments that intrude upon the traditional domain of the states. This follows from the notion that the states, through their representatives, are deemed to have "acquiesced" in the enactment of constitutional and congressional law. Federal courts, however, should not promulgate federal common law rules that intrude upon that domain unless they have been authorized to do so by an enacting body in which the states are represented. This follows from a corollary to the Wechsler-Garcia thesis: states cannot be automatically deemed to acquiesce in whatever federal judges may consider to be appropriate public policy. The test under this approach is thus neither the wisdom of the policy invoked by a federal judge nor the extent of its intrusion upon state interests, but whether there has been actual or implied acquiescence or ratification by the states.

The Wechsler-Garcia thesis further suggests that federal courts may "interpret" constitutional provisions and congressional legislation, so long as interpretation is understood to mean a search for the specific intentions of the enacting body. Since the states are directly represented in Congress and in the process of constitutional ratification, a showing that either Congress or the framers of the Constitution specifically intended a given legal rule is tantamount to a finding that the states, through their representatives, acquiesced in the rule. By contrast, if courts "interpret" a federal text in some way that was not specifically intended by the enacting body - for example, by invoking their own understanding of contemporary political morality-acquiesence by representatives

\footnotetext{
71 Significantly, the Garcia Court coupled its abrogation of controls on congressional interference in state affairs with a strong statement disapproving federal judicial interference in state affairs. Indeed, one of the grounds for overruling National League of Cities was that it invited "an unelected federal judiciary to make decisions about which state policies it favors and which ones it dislikes." Garcia v. San Antonio Metro. Transit Auth., 105 S. Ct. 1005, 1015 (1985).
} 
of the states cannot be presumed. Thus, to borrow from the terminology of modern constitutional theory, the Wechsler-Garcia version of judicial federalism is consistent with an "originalist" mode of textual interpretation, but is not necessarily consistent with a "nonoriginalist" mode. ${ }^{72}$

The federalism principle, in any of its forms, is applicable only when federal law interferes with actual state interests. This in turn suggests that federal common law rules pertaining to federal court procedure or internal governance, for example, should never be held to violate the federalism principle unless they can be shown to conflict in some manner with identifiable state interests. Thus, the principle of judicial federalism is consistent with the notion that federal courts enjoy certain "implied powers" that are inherent in "the nature of their institution" " 3 _ powers related to the conduct of trials and other matters of judicial "housekeeping."

Finally, the federalism principle, even in its attenuated modern form, is important because it tells us what law must apply if federal common law turns out to be illegitimate on any ground. The federalism principle describes the choice confronting federal courts in determining what rule of law to apply: either federal law (including federal common law) supplies the rule, or state law supplies the rule. ${ }^{74}$ The reservation to the states or the people of all

${ }^{72}$ Academic commentators hostile to originalism often argue that ascertaining the original meaning of a text is so difficult and so fraught with historiographical and conceptual problems - such as the difficulty of "summing" the beliefs of multiple actors-as to be virtually impossible. See, e.g., Brest, supra note 8, at 211-23; Tushnet, supra note 41, at 798-804. I would agree that, at least in the context of constitutional interpretation, the search for the specific intentions of the framers will often be futile. But the argument that one can never grasp the original intentions of the draftsmen of a text represents an extreme form of skepticism that would deny the possibility of any form of historical understanding. See Perry, supra note 42 . Notwithstanding the historiographical and conceptual problems, "the core question remains: do the basic postulates of the constitutional order require that the court undertake the task of ascertaining original intent, as best it can?" Monaghan, supra note 35, at 377 (emphasis in original).

73 United States v. Hudson \& Goodwin, 11 U.S. (7 Cranch) 32, 34 (1812); see also Westen \& Lehman, supra note 7, at 329 (federal courts possess internal rulemaking powers); $c f$. Hanna v. Plumer, 380 U.S. 460, $472-73$ (1965) (Constitution's provision for a system of federal courts implies congressional power to make rules for those courts); Herron v. Southern Pac. Co., 283 U.S. 91, 94-95 (1931) (same).

${ }^{74}$ Westen and Lehman argue that, in the absence of a relevant and legitimate federal rule, state law does not apply of its own force but only because "Congress has chosen to apply it." Westen and Lehman, supra note 7, at 357. This is correct insofar as it means that Congress usually could specify a federal rule that would apply. Insofar as Westen and Lehman intimate that federal courts have any choice but to apply relevant state law when there is no relevant and legitimate federal rule, however, their statement is misleading. In these circumstances, the federalism principle and the Rules of Decision Act compel the court to apply the state-law rule. From the courts' perspective, therefore, state law applies in default 
powers not exercised by the federal government means that whenever federal common law cannot legitimately be applied, then federal courts must look to state law to supply the rule.

\section{B. Separation of Powers}

The second general restraint on lawmaking by federal courts is grounded in the Constitution's division of powers within the federal government between the legislative and judicial branches. Article I provides that "[a]ll legislative Powers herein granted shall be vested in a Congress of the United States . . . ."7s Article III provides that " $[t]$ he judicial Power of the United States, shall be vested in one supreme Court, and in such inferior Courts as the Congress may from time to time ordain and establish."76 Given this division of powers, the Supreme Court has concluded that "the federal lawmaking power is vested in the legislative, not the judicial, branch of government."

From an originalist perspective, there can be little doubt that the separation-of-powers concept has implications for the federal judicial role. The framers, following Montesquieu, believed that government power had to be divided in order to guard against "tyranny"- that is, government encroachment on private rights of liberty and property. The executive and (especially) the legislative branches were most feared; the judiciary, in Hamilton's phrase, was the "least dangerous to the political rights of the Constitution."78 But the danger of judicial usurpation was also acknowledged; it is significant that this danger was expressed with reference to judicial lawmaking. As Hamilton put it, courts might be "disposed to exercise wILL instead of JUDGMENT" or to indulge in "the substitution of their pleasure to that of the legislative body." "79 Under the constitutional scheme, this form of judicial tyranny was to be avoided in part by depriving the judiciary of any

of federal law "because there can be no other law." Hanna v. Plumer, 380 U.S. 460, 472 (1965).

75 U.S. Const. art. I, § 1.

76 U.S. ConsT. art. III, § 1.

77 Northwest Airlines v. Transport Workers Union, 451 U.S. 77, 95 (1981); see also Addison v. Holly Hill Fruit Prods., Inc., 322 U.S. 607, 618 (1944) (the judicial function of construing legislation is distinct from the lawmaking function itself).

${ }^{78}$ The Federalist No. 78, at 465 (A. Hamilton) (C. Rossiter ed. 1961); cf. id. No. 48, at 309 (J. Madison) ("The legislative department is everywhere extending the sphere of its activity and drawing all power into its impetuous vortex.").

79 Id. No. 78, at 469 (A. Hamilton); see also id. No. 81, at 482-83, 484-85 (A. Hamilton). 
"influence over either the sword or the purse" for impeachment in cases of judicial misbehavior ${ }^{81}$ But the principal barrier was self-restraint. Federal judges would have to be men of independence and learning who would subordinate their own will to that of the framers or the legislature in cases involving textual interpretation. ${ }^{82}$

More important from the perspective of the internal norm, the vitality of the separation-of-powers principle is evident in the decisions of the contemporary Supreme Court. Consider, for example, the following passage from TVA $v$. Hill, the celebrated "snail darter" case:

Our system of government is, after all, a tripartite one, with each branch having certain defined functions delegated to it by the Constitution. While "[i]t is emphatically the province and duty of the judicial department to say what the law is," ... it is equally - and emphatically - the exclusive province of the Congress not only to formulate legislative policies and mandate programs and projects, but also to establish their relative priority for the Nation. Once Congress, exercising its delegated powers, has decided the order of priorities in a given area, it is for the Executive to administer the laws and for the courts to enforce them when enforcement is sought. ${ }^{83}$

The rhetoric of this case is not an isolated phenomenon; ${ }^{84}$ if anything, as the powers of the federal government have grown in relation to those of the states, the separation-of-powers principle has probably eclipsed federalism as the dominant ground for questioning lawmaking by federal courts. ${ }^{85}$

${ }^{80}$ Id. No. 78, at 465 (A. Hamilton).

${ }^{81}$ Id. No. 79, at 474 (A. Hamilton).

${ }^{82}$ Id. No. 78 , at 469-72 (A. Hamilton).

${ }_{83}$ TVA v. Hill, 437 U.S. 153, 194 (1978) (quoting Marbury v. Madison, 5 U.S. (1 Cranch) 137, 177 (1803)).

84 The Court has often stated that the formulation of national policy lies in the congressional domain, not its own. See, e.g., City of Milwaukee v. Illinois, 451 U.S. 304, 312-14 (1981); Diamond v. Chakrabarty, 447 U.S. 303, 317 (1980); see also Cannon v. University of Chicago, 441 U.S. 677, 730-31 (1979) (Powell, J., dissenting). But cf. Merrill Lynch, Pierce, Fenner \& Smith, Inc. v. Curran, 456 U.S. 353, 374-82 (1982) (rejecting separation-of-powers challenge to judicial formulation of implied private rights of action).

${ }^{85}$ A good example of this is the discussion of federal common law in City of Milwaukee v. Illinois, 451 U.S. 304 (1981). The Court began by citing Erie for the proposition that "[f]ederal courts, unlike state courts, are not general common-law courts and do not possess a general power to develop and apply their own rules of decision." Id. at 312. The Court went on, however, to explain the reason for this limitation on the lawmaking power of federal courts in terms of separation-of-powers and electoral-accountability norms, not in terms 
Of course, the notion that Congress is the exclusive federal lawmaking body is an oversimplification of constitutional reality-not only the reality of today, in which administrative agencies churn out reams of edicts having the force of law, ${ }^{86}$ but also the reality presented by the Constitution itself. This is particularly true with respect to the interplay between the executive and legislative branches, where the President takes part in legislative functions through the power of the veto. ${ }^{87}$ In this and other areas, the constitutional reality is "not a government of separated powers, but rather a government of separated institutions sharing powers." 88

Nevertheless, the fact that the Constitution permits some sharing of the lawmaking power with the executive branch does not require us to conclude that the Constitution erects a system of shared powers with respect to lawmaking by the federal courts. Neither the text of the Constitution nor the history of the Federal Convention gives any indication that the federal courts are to partake of an advisory, amendatory, or supplementary role in the formulation of legislation. ${ }^{89}$ Moreover, the example of wholesale lawmaking by independent and executive-branch agencies is distinguishable on grounds both of federalism and of electoral accountability. The agencies are either appointed or removable by

of the federalism analysis of Erie. Id. at 313-14.

${ }^{86}$ The Supreme Court has allowed Congress to delegate its legislative power to the executive branch, provided that the enabling legislation sets forth an "intelligible principle" that confines the discretion of the agency. See, e.g., A.L.A. Schechter Poultry Corp. v. United States, 295 U.S. 495, 529-30 (1935); J.W. Hampton, Jr., \& Co. v. United States, 276 U.S. 394, 405-13 (1928). In recent years, courts have upheld delegations of legislative power that provided only the sketchiest of standards, see, e.g., Amalgamated Meat Cutters v. Connally, 337 F. Supp. 737, 747-49 (D.D.C. 1971) (three-judge court) (power to "stabilize" prices), although there are signs that this may change, see, e.g., American Textile Mfrs. Inst. v. Donovan, 452 U.S. 490, 547-48 (1981) (Rehnquist, J., dissenting) (congressional delegation to OSHA to regulate workplace hazards "to the extent feasible" is unconstitutional abdication of legislative power); Industrial Union Dep’t v. American Petroleum Inst., 448 U.S. 607, 675 (1980) (Rehnquist, J., concurring) (same). For example, the Court's willingness to strike down the legislative veto on separation-of-powers grounds is difficult to reconcile with a highly relaxed approach to legislative delegation. See INS v. Chadha, 103 S. Ct. 2764, 280104 (1983) (White, J., dissenting).

${ }^{87}$ U.S. Const. art. I, § 7, cl. 2; cf. INS v. Chadha, 103 S. Ct. 2764, 2782-83 (1983) (legislative act not presented to President for signature or possible veto invalid under the Constitution).

${ }^{88}$ Frohnmayer, The Separation of Powers: An Essay on the Vitality of a Constitutional Idea, 52 OrE. L. REv. 211, 218-19 (1973) (footnote omitted).

${ }^{89}$ The clearest evidence of this is, no doubt, the Convention's rejection of Edmund Randolph's proposal for a Council of Revision, to be composed of the President and members of the federal judiciary, which was to have the power to veto congressional legislation. The episode is reviewed in R. BERgER, supra note 9, at 300-06. 
the President, and the President is answerable to the states and the people through periodic elections-federal judges are not.

There are two important counterarguments to the separationof-powers principle reflected in the Constitution and invoked in cases such as TVA $v$. Hill. The first is based on the possibility of congressional override of judicial lawmaking. Most federal common law-including statutory construction, judge-made procedural rules, and implied rights of action-is "subject to the paramount authority of Congress." ${ }^{90}$ Only those forms of federal common lawmaking that purport to derive their authority directly from the Constitution-most notably nonoriginalist judicial review-are binding on Congress and thus subject to override only by constitutional amendment. With respect to most forms of federal common law, therefore, if Congress disapproves of the law made by federal courts, it can step in and reverse the judicial decision with legislation of its own, thus preserving the principle of congressional supremacy. Where Congress can override judicial policymaking, the argument runs, the separation-of-powers problem disappears. ${ }^{91}$

There are two responses to this counterargument. First, the fact that "the legislature can protect itself against judicial invasion of its sphere does not justify that invasion in the first place." ${ }^{\text {92 }}$ If, as the constitutional text suggests, the legislative power belongs primarily to Congress, then the federal judiciary has no more authority than the President or an administrative agency to "make law" on its own initiative, absent a delegation from Congress. Indeed, the Supreme Court itself has not accepted the view that the possibility of congressional override obviates separation-of-powers concerns about the legitimacy of federal common law..$^{93}$

The second response is more pragmatic. The argument based on the possibility of congressional override ignores the institutional reality that, given its crowded agenda, Congress is far more likely not to act than to act with respect to any particular issue

${ }^{\text {90 }}$ City of Milwaukee v. Illinois, 451 U.S. 304, 313 (1981) (quoting New Jersey v. New York, 283 U.S. 336, 348 (1931)).

${ }^{21}$ For representative examples of the argument that the possibility of congressional override either precludes or substantially eliminates any separation-of-powers objection to lawmaking by federal courts, see G. CALABRESI, supra note 10, at 92-93; Monaghan, supra note 12 , at 34 .

${ }^{82}$ Schrock \& Welsh, supra note 39 , at 1128 .

${ }^{93}$ See City of Milwaukee v. Illinois, 451 U.S. 304, 313 (1981) ("Nothing in this process [of formulating federal common law] suggests that courts are better suited to develop national policy in areas governed by federal common law than they are in other areas, or that the usual and important concerns of an appropriate division of functions between the Congress and the federal judiciary are inapplicable."). 
presented for its attention. ${ }^{94}$ The theoretical possibility of congressional override cannot disguise the fact that lawmaking by federal courts would in most cases give the last word to the federal courts rather than to Congress. In practice, therefore, institutionalization of lawmaking by federal courts would represent a major shift in policymaking power away from Congress and toward the federal judiciary, in violation of the constitutional scheme. ${ }^{95}$

The second counterargument to the separation-of-powers thesis is somewhat more troubling. Under the typical formulation of the thesis, such as that stated in the passage from TVA v. Hill quoted above,$^{96}$ federal courts are said to have no power to "make law," but they are conceded to have the power to "interpret" the law-" "to say what the law is." "97 This raises squarely the central difficulty in any account of federal common law: when does legitimate textual "interpretation" stop and illegitimate judicial "lawmaking" begin?

Even without a comprehensive examination of this problem, it should be apparent that the separation-of-powers principle, like the federalism principle, is at least consistent with "interpretation" in the conventional sense of a quest for the specific intentions of the enacting body. If the legislative power belongs primarily to Congress, then it should not be regarded as a usurpation of that power for courts to interpret legislation to reach results that were specifically intended by Congress. Similarly, if the power to frame and revise the Constitution belongs to the people (acting through conventions or through their elected representatives in Congress and state legislatures), then it should not be regarded as a usurpation for the courts to interpret the Constitution to reach results

94 See, e.g., Grant Gilmore, The Ages of American Law 95-96 (1977) ("On the federal level it is difficult to the point of impossibility to draw the attention of a crisis-ridden Congress to any area of law reform which, although it may be urgent, has not erupted in political controversy."); G. CALABRESI, supra note 10 , ch. 1 .

${ }^{95}$ As Westen and Lehman observe:

[I]f the courts were motivated only by the fear of actually being legislatively overruled, they would feel free to disregard their best assessment of what legislators probably desire and to substitute their own judgment instead, except where their own judgment so dramatically departed from what legislators desired that the legislature could be expected to overrule them. Such substitution of judicial judgment for legislative judgment-based on an unprincipled exploitation of legislative "inertia"-is improper, because the very justification for the court's authority in this area is to give effect to legislative will.

Westen \& Lehman, supra note 7 , at 337 n.86.

${ }^{96}$ See supra note 83 and accompanying text.

${ }_{97}$ TVA v. Hill, 437 U.S. 153, 194 (1978) (quoting Marbury v. Madison, 5 U.S. (1 Cranch) 137,177 (1803)). 
that the framers sought to constitutionalize. In either case, construing the text to further the specific intentions of the enacting body enhances, rather than detracts from, the enacting body's power. Thus, the separation-of-powers principle, like the federalism principle, supports an "originalist" mode of textual interpretation, but not necessarily a "nonoriginalist" mode..$^{98}$

Furthermore, as in the case of the federalism principle, there would seem to be no separation-of-powers objection to judicial formulation of rules governing either the conduct of litigation in the federal courts or internal court governance. Since the separationof-powers principle is concerned only with judicial intrusion into the lawmaking function of Congress, the promulgation of "housekeeping" rules that would have no impact on congressional policies is consistent with the constitutional division of powers. Of course, it is well established that if Congress wishes to prescribe procedural rules for the federal courts, it has the authority to do so; ${ }^{99}$ and Congress has exercised this power, most notably with the enactment of the Rules Enabling Act. ${ }^{100}$ In the absence of congressional action, however, federal courts should be regarded as having inherent authority to adopt their own provisions governing the conduct of litigation and internal operations without violating any principle of separation of powers.

\section{Electoral Accountability}

The third general principle bearing on the legitimacy of lawmaking by federal courts-and the last derived directly from the provisions of the Constitution-is what I call "electoral accountability": the principle that public policy should be made by officials who are answerable to the people through periodic elections. ${ }^{101}$

In contrast to the federalism and separation-of-powers princi-

${ }^{98}$ As Chief Justice Marshall said in Osborn v. Bank of the United States, 22 U.S. (9 Wheat.) 738, 866 (1824), "Judicial power is never exercised for the purpose of giving effect to the will of the judge; always for the purpose of giving effect to the will of the legislature; or, in other words, to the will of the law."

${ }^{99}$ Sibbach v. Wilson \& Co., 312 U.S. 1, 9-10 (1941); Wayman v. Southard, 23 U.S. (10 Wheat.) 1,22 (1825).

10028 U.S.C. $\S 2072$ (1982).

101 I prefer the term "electoral accountability" to the more commonly encountered terms "majoritarianism" or "democratic theory" because it seems less freighted with normative implications about the substantive merit of decisions that conform to the principle. By "electoral accountability" I mean essentially what Michael Perry means by "direct electoral accountability": a person is electorally accountable "if he holds elective office for a designated, temporary period and can remain in office beyond that period only by winning reelection." M. PERRY, supra note 9, at 9. 
ples, which restrain the lawmaking powers of federal courts directly, the principle of electoral accountability is only indirectly relevant to the power of federal courts to make federal law. Under the Constitution, it is clear that federal courts are not intended to be electorally accountable. They are and always have been an appointed body enjoying life tenure and secured compensation. ${ }^{102}$ Moreover, virtually everyone seems to regard this as desirable: there is no serious movement afoot to subject federal judges to periodic elections. Under the internal norm of legitimacy, therefore, the fact that federal judges are not electorally accountable cannot by itself be an objection to judicial lawmaking.

Nevertheless, the electoral-accountability principle is important insofar as it reinforces the separation-of-powers principle. As I pointed out above, ${ }^{103}$ the Constitution confers the power to "make law" on Congress (with the participation of the President through the power of the veto). The judiciary is not to make law but only to enforce or "interpret" the law-understanding interpretation, at least for now, to mean the search for the specific intentions of the legislature. Given this division of powers, if the Constitution also makes Congress (and indeed the President) electorally accountable, then a violation of the principle of separation of powers will also, derivatively, be a violation of the principle of electoral accountability. ${ }^{104}$

As originally enacted, the Constitution did not provide that Congress and the President were to be electorally accountable as we tend to understand that concept today. Only the House of Representatives was elected directly by the people. The Senate was elected by the state legislatures, ${ }^{105}$ and the President was elected by an electoral college appointed in a manner directed by the state legislatures. ${ }^{108}$ More important, the electorate was a rather exclusive group: all women, virtually all blacks, and anyone not meeting property qualifications set by the states were denied suffrage. ${ }^{107}$

102 U.S. Const. art. III, § 1.

${ }^{103}$ See supra notes 75-100 and accompanying text.

104 Many constitutional theorists do not view electoral accountability as derived from separation of powers but rather as a direct limitation on federal judicial lawmaking. See, e.g., M. Perry, supra note 9, at 9, 28-29 ("axiomatic" to Americans that governmental value choices must be made by electorally accountable officials). For these commentators, electoral accountability is an "external" norm inherent in the notion of democracy and is prior to the particular "internal" norms established by the structure of the Constitution.

105 U.S. Const. art. I, § 3, cl. 1, amended by U.S. Const. amend. XVII.

${ }_{106}$ U.S. Const. art. II, $\S 1$, cl. 2, amended by U.S. Const. amend. XII.

${ }_{107}$ The qualifications to vote for members of the House of Representatives were those "requisite for Electors of the most numerous Branch of the State Legislature." Id. Black 
As is well known, however, the Constitution's commitment to popular accountability of the "lawmaking" branches has increased dramatically over the years. By constitutional amendment, the Senate is now elected directly by the people, ${ }^{108}$ and by universal practice the electors selecting the President are elected directly by the people. ${ }^{109}$ Further constitutional amendments provide specific guarantees that the franchise will not be restricted on account of race or color, ${ }^{110}$ sex, ${ }^{111}$ age (above 18 ), ${ }^{112}$ or failure to pay taxes. ${ }^{113}$ Thus, electoral accountability is today a firmly established component of the internal norm, underscoring the importance of the principle of separation of powers. ${ }^{114}$

It is frequently asserted that the electoral-accountability principle is violated only when courts make constitutional law, and thus that it has no bearing on other forms of federal common law. ${ }^{115}$ The argument for this proposition is the same as in the context of the separation-of-powers principle: if federal common law can be reversed by ordinary legislation, then the electorally accountable branches can have the last word, and the principle of accountability is preserved from judicial usurpation. The answer to the argument, however, is also the same: the potential for legislative override does not justify violation of the accountability principle in the first place; furthermore, legislative override would not take place very often in practice, and judicial lawmaking therefore erodes the principle that, under the Constitution, public policy is to be determined by officials answerable to the people.

To be sure, the many commentators who have distinguished

freedmen were apparently denied the vote in all states except Massachusetts, see $\mathrm{H}$. PloskI \& J. Williams, The Negro Almanac: A Reference Work on the Afro-American 6 (4th ed. 1983), as were black slaves in all states. On property qualifications imposed by the states, see Chilton Williamson, American Suffrage: From Property to Democracy, 1760-1869, ch. 7 (1960). Of over 3,000,000 inhabitants of the United States at the close of the Revolutionary War, fewer than five percent actually qualified to vote in House elections. H. PLOSKI \& J. Williams, supra, at 355.

108 U.S. ConsT. amend. XVII.

100 John Hart Ely reports that by 1832 only South Carolina persisted in the practice of having electors chosen by the state legislature; since 1860 the electors have been chosen directly by the people in all states. J. ELY, supra note 9 , at 6 .

110 U.S. ConsT. amend. XV.

111 Id. amend. XIX.

112 Id. amend. XXVI.

113 Id. amend. XXIV.

114 For a recent decision that expressly relies upon the principle of electoral accountability to limit the lawmaking power of federal courts, see Chevron, U.S.A., Inc. v. National Resources Defense Council, Inc., 104 S. Ct. 2778, 2793 (1984) (“[F]ederal judges-who have no constituency-have a duty to respect legitimate policy choices of those who do.").

115 E.g., J. Ely, supra note 9, at 4-5, 67-68; M. PerRy, supra note 9, at 28 n.*. 
constitutional adjudication from other types of federal common lawmaking on the basis of its implications for electoral accountability are correct. Constitutional lawmaking offers the more profound challenge to the principle of electoral accountability. Constitutional lawmaking-including nonoriginalist judicial review-can be overridden only by a constitutional amendment, which ordinarily requires ratification by three-fourths of the state legislatures. ${ }^{116}$ Other forms of judicial lawmaking can be overridden by a simple majority of Congress with the concurrence of the President. Although lawmaking that purports to derive its authority from the Constitution thus presents a stronger challenge than other types of federal common lawmaking to the accountability principle, it does not follow that there is no objection to the other forms of lawmaking. ${ }^{117}$ Any exercise of lawmaking by federal courts represents a potential erosion of the principle of electoral accountability and hence presents a problem of legitimacy.

Because the electoral-accountability principle, as an internal norm, is derived from the separation-of-powers principle, the limitations on the powers of federal courts under this principle are essentially the same as those derivable under the separation-of-powers principle. This means that federal courts are limited to interpreting federal texts (initially understood as a search for the specific intentions of the enacting body) and to fashioning their own procedural and housekeeping rules for the conduct of litigation in federal courts.

\section{The Rules of Decision Act}

Up to this point, I have discussed constitutionally based objections to lawmaking by federal courts. I turn now to statutory sources. Congress could enact a statute prohibiting lawmaking by

116 U.S. CoNsT. art. V. An alternative mode of ratification (through state conventions) has only been used once. See id. amend. XXI, § 3 (repealing id. amend. XVIII). Amendments cannot even be proposed until two-thirds of both houses of Congress or the legislatures of two-thirds of the states deem it necessary to do so. Id. art. V.

117 It is occasionally argued that enforcement of "old" texts written by "dead hands" is also incompatible with the principle of electoral accountability. See, e.g., J. ELy, supra note 9, at 11-12. The weakness of this argument is that it overlooks the fact that the electoralaccountability principle, at least when viewed as an internal norm, see supra note 104, is derived from the separation-of-powers principle. Electoral accountability is a constitutional constraint on lawmaking by federal judges only because the Constitution assigns the "legislative power" to Congress. Enforcement of old texts cannot offend separation of powers because congressmen inevitably die or retire and statutes, unless repealed, live on. Thus, enforcement of old texts would be incompatible with electoral accountability only if electoral accountability were understood as some kind of preconstitutional, external norm. 
federal courts, and federal courts would be free to disregard such a statute only if it were unconstitutional. Given the principles of federalism, separation of powers, and electoral accountability just surveyed, there can be little doubt that, provided such a statute conformed to these principles, it would be constitutional. ${ }^{118}$

In fact, it would seem that Congress has enacted just such a statute. The Rules of Decision Act ${ }^{119}$ first appeared as part of the Judiciary Act of $1789^{120}$ and remains a part of the Judicial Code to this day. The Act currently provides that " $[t]$ he laws of the several states, except where the Constitution or treaties of the United States or Acts of Congress otherwise require or provide, shall be regarded as rules of decision in civil cases in the courts of the United States, in cases where they apply." The statute establishes the sources of the "rules of decision" to be applied by federal courts in civil litigation. Where the Constitution, treaties, or statutes of the United States "require or provide" a rule of decision, the rule is federal. Where the Constitution, treaties, or statutes of the United States do not "require or provide" a rule of decision, the rule is to be gathered from "the laws of the several states." Because the federal courts must take the Constitution, treaties, and statutes of the United States as a given and have no say in determining the content of the "laws of the several states," the Rules of Decision Act appears to be a severe restriction on lawmaking by federal courts. ${ }^{121}$

As originally enacted, the Rules of Decision Act directed federal courts to apply state law in all "trials at common law in the courts of the United States." ${ }^{22}$ Thus, the Act was not limited to

118 Thus, a statute forbidding federal courts to interpret the Constitution or federal statutes in a manner contrary to the original intentions of the draftsmen of those instruments would be constitutional because it would be consistent with the principles of federalism, separation of powers, and electoral accountability. This does not mean, however, that any statute prohibiting judicial lawmaking would be constitutional. For instance, an extremely drastic limitation on judicial lawmaking - such as a statute forbidding federal courts to engage in any form of textual interpretation whatsoever-might violate separation of powers by encroaching on the "judicial power" granted to federal courts by article III. The Supreme Court has consistently interpreted the judicial power to include the power "to say what the law is." See, e.g., Marbury v. Madison, 5 U.S. (1 Cranch) 137, 177 (1803); TVA v. Hill, 437 U.S. 153, 194 (1978).

11928 U.S.C. $\S 1652(1982)$.

1201 Stat. 73 (1789).

121 See generally Comment, supra note 4 (proper view of Rules of Decision Act would leave little room for federal common lawmaking).

122 The original Act provided:

Sec. 34. And be it further enacted, That the laws of the several states, except where the constitution, treaties or statutes of the United States shall otherwise require or 
cases brought under the diversity jurisdiction. By implication, however, three other classes of cases were not covered: criminal trials, cases in equity, and cases in admiralty. Of course, given the constitutional constraints of federalism and separation of powers (and today, electoral accountability), the absence of a statutory restriction on judicial lawmaking in these cases should not be taken as a license to expand the powers of the courts. Unless the concerns of federalism, separation of powers, and electoral accountability are satisfied, judicial lawmaking should be deemed just as illegitimate in these classes of cases as in "trials at common law." ${ }^{23}$ After several false starts and peregrinations, the Supreme Court eventually arrived at this view.

The conclusion was reached rather quickly with respect to criminal trials. In United States v. Hudson \& Goodwin, ${ }^{124}$ the Court held that the federal circuit courts had no authority to try common law crimes. Reasoning from federalism and separation-ofpowers premises, the Court concluded that before the federal courts could adjudicate a criminal charge, Congress "must first make an act a crime, affix a punishment to it, and declare the Court that shall have jurisdiction of the offence."125

With respect to cases in equity, the path was much more complicated. From its beginnings and through the nineteenth century, the Court, in the spirit of Swift $v$. Tyson, ${ }^{126}$ generally considered itself free to expound rules of decision in equity drawn from English precedent and principles of "general law." ${ }^{127}$ After Swift was overruled by Erie, however, the Court rather quickly concluded that the Rules of Decision Act was "merely declaratory of what would in any event have governed the federal courts and therefore was equally applicable to equity suits." ${ }^{128}$ In 1948, Congress amended the Rules of Decision Act to confirm this construction. ${ }^{\mathbf{1 2 9}}$

provide, shall be regarded as rules of decision in trials at common law in the courts of the United States in cases where they apply.

1 Stat. 73 (1789).

${ }^{123}$ See Mason v. United States, 260 U.S. 545, 559 (1923) (Rules of Decision Act “merely declarative of the rule which would exist in the absence of the statute").

12411 U.S. (7 Cranch) 32 (1812); see also United States v. Coolidge, 14 U.S. (1 Wheat.) 415 (1816).

12511 U.S. (7 Cranch) at 34.

${ }^{128} 41$ U.S. (16 Pet.) 1 (1842), overruled, Erie R.R. v. Tompkins, 304 U.S. 64 (1938).

127 See, e.g., Payne v. Hook, 74 U.S. (7 Wall.) 425, 430 (1868) ("The equity jurisdiction conferred on the Federal courts is the same that the High Court of Chancery in England possesses; is subject to neither limitation or restraint by State legislation, and is uniform throughout the different States of the Union.").

${ }_{128}$ Guaranty Trust Co. v. York, 326 U.S. 99, 103-04 (1945) (footnote omitted).

129 Act of June 25, 1948, ch. 646, Pub. L. No. 80-773, 62 Stat. 869, 944 (codified at 28 
The history with respect to maritime cases is oddly different. There, as with cases in equity, early federal courts deemed themselves free to fashion rules of decision based on "general" principles of maritime law. ${ }^{130}$ In contrast with equity, however, this form of federal common lawmaking has survived Erie; article III's grant of jurisdiction over maritime cases has been held to constitute not only a grant of jurisdiction but also a grant of power to fashion substantive rules of decision. ${ }^{131}$ However anomalous this may be as an interpretation of article III, ${ }^{132}$ it nevertheless serves to reconcile the "maritime exception" with the concerns of federalism, separation of powers, and electoral accountability that limit the lawmaking power of federal courts in other contexts.

Another interpretive problem that for a time reduced the force of the Rules of Decision Act involves the meaning of the phrase "the laws of the several states." In Swift v. Tyson, ${ }^{133}$ Justice Story concluded that the word "laws" referred only to "the positive statutes of the state, and the construction thereof adopted by the local tribunals, and to rights and titles to things having a permanent locality . . . ."134 "Laws" did not refer to common law decisions pertaining to "questions of a more general nature . . .."135 Thus, Story concluded, the Act did not present a bar to lawmaking by federal courts with respect to these "general" issues. In Erie, of course, the Supreme Court held that if Story's interpretation of the Rules of Decision Act were correct, the Act would be unconstitutional because of the federalism objection. ${ }^{136}$ This conclusion is reinforced by separation-of-powers and electoral-accountability considerations.

Given the Court's interpretation in Erie, one would assume that the Rules of Decision Act would today be regarded as a potent

\footnotetext{
U.S.C. § $1652(1982))$.

130 See, e.g., De Lovio v. Boit, 7 F. Cas. 418 (C.C.D. Mass. 1815) (No. 3766) (Story, J.).

${ }^{131}$ See, e.g., Northwest Airlines v. Transport Workers Union, 451 U.S. 77, $96-97$ (1981) (distinguishing common law powers of federal courts under admiralty jurisdiction from powers in other contexts). Indeed, the jurisdictional grant over "all Cases of admiralty and maritime Jurisdiction," U.S. ConsT. art. III, § 2, cl. 1, has come to be viewed as a grant of lawmaking power to Congress as well as the courts. See Note, From Judicial Grant to Legislative Power: The Admiralty Clause in the Nineteenth Century, 67 HaRv. L. REv. 1214, 1230-37 (1954).

${ }_{132}$ See M. REDISH, supra note 10, at 98-99 (noting inconsistency between lawmaking powers of federal courts under diversity jurisdiction and admiralty jurisdiction, and suggesting the abolition of an independent federal common law of admiralty).

${ }_{133} 41$ U.S. (16 Pet.) 1 (1842), overruled, Erie R.R. v. Tompkins, 304 U.S. 64 (1938).

13441 U.S. (16 Pet.) at 18.

138 Id.

${ }^{136}$ Erie R.R. v. Tompkins, 304 U.S. 64, 78-80 (1938).
} 
barrier to federal judicial lawmaking. Yet the current status of the Rules of Decision Act is something of a puzzle. In general, the modern Supreme Court treats the Act not as a barrier to lawmaking but "as if it did not exist." ${ }^{137}$ Moreover, in a footnote in a recent decision, the Court seemed to argue that although the Act mandates that federal law apply when a federal statute so "requires or provides," it does not mandate that state law apply when a federal statute is silent. ${ }^{138}$ This appears to contradict the language of the Act. Whether this footnote presages outright judicial nullification of "the great statutory charter of federalism"139 remains to be seen. In any event, since the Act has been held to be "merely declarative of the rule which would exist in the absence of the statute"140 (and absent a more definitive interment from the Court), I will assume that the Act continues to operate as an independent statutory barrier to lawmaking by federal courts.

Of course, even if the Rules of Decision Act limits lawmaking by federal courts, it does not necessarily follow that it prohibits all forms of textual interpretation. The Act says that state law must govern unless "the Constitution or treaties of the United States or Acts of Congress otherwise require or provide"-it does not say that state law governs unless some federal rule of decision is set forth on the face of an authoritative text. The phrase "require or provide" is broad enough to embrace at least some interpretation

137 P. Kurland, supra note 65, at 62.

138 DelCostello v. International Bhd. of Teamsters, 103 S. Ct. 2281, 2287-88 n.13 (1983). But see id. at 2295 (Stevens, J., dissenting) (federal courts can apply federal rules of decision only when the Constitution, treaties, or statutes of the United States specifically so provide); Carlson v. Green, 446 U.S. 14, 37-38 (Rehnquist, J., dissenting) (federal authority to fashion remedies lies with Congress, not the courts). The DelCostello footnote suggests that all gaps in federal statutes are to be filled by federal common law; state rules of decision may be "adopted" as the federal common law rule, but if so, they are adopted as a matter of discretion rather than because the federalism principle or the Rules of Decision Act requires that they be adopted. See supra note 74 . There are two possible grounds for reaching such a conclusion. One ground, which is hinted at in the footnote, is that the federalism principle embodied in Erie and the Rules of Decision Act applies only in diversity cases. Neither the constitutional analysis of Erie nor the text of the Rules of Decision Act supports this contention. The other ground, which is also hinted at, is that when Congress passes a federal statute, it can be presumed to intend that all gaps be filled by federal common law. This notion of presumed intent is too broad to accord with the internal norm of legitimacy. As I will argue below, in many instances (of which DelCostello may be one), federal common law can be legitimately applied to fill gaps in federal statutes, but only if the conditions for either preemptive or delegated lawmaking are met. See infra notes 147-57 and accompanying text.

138 Hart, supra note 4 , at 504.

140 Mason v. United States, 260 U.S. 545, 559 (1923); see also Guaranty Trust Co. v. York, 326 U.S. 99, 103-04 (1945) (quoted supra text accompanying note 128). 
of federal texts, and thus to support the creation of some federal common law. Indeed, commentators have asserted that the Rules of Decision Act presents no barrier to federal common law because any federal common law rule can be described as a form of textual "interpretation." ${ }^{141}$ As I suggested at the beginning of this article, however, this involves a highly questionable view of what can legitimately be described as textual "interpretation." A more cautious conclusion would be that the Rules of Decision Act is at least consistent with what is conventionally thought of as "interpretation"-enforcing the intentions of the draftsmen of the text.

In addition-although this is generally overlooked-the Act applies only to the derivation of "rules of decision" in federal court. As Professor William Crosskey pointed out, ${ }^{142}$ the phrase "rules of decision" was probably used by the first Congress in contradistinction to the phrase "rules of process"; ${ }^{143}$ hence the Rules of Decision Act was probably intended to constrain the lawmaking powers of federal courts with respect to "substantive" as opposed to "procedural" issues. Thus, it would seem that the Rules of Decision Act, like the federalism, separation-of-powers, and electoralaccountability principles, imposes no constraint on federal courts with respect to the formulation of judge-made procedural rules or rules of internal governance not rising to the dignity of grants of substantive rights. ${ }^{144}$

\section{Preemptive and Delegated Lawmaking}

So far, the analysis of the internal norm of legitimacy suggests that federal common law is legitimate only if it rests on a search for the specific intentions of the draftsmen of authoritative texts,

141 Westen \& Lehman, supra note 7, at 331.

$1422 \mathrm{~W}$. Crosskey, supra note 53, at 820-21.

${ }^{143}$ Five days after the enactment of the Judiciary Act, which included the Rules of Decision Act, Congress passed "An Act to regulate Processes in the Courts of the United States." 1 Stat. 93 (1789). The Process Act provided that "the forms of writs and executions . . . and modes of process . . . shall be the same in each state respectively as are now used or allowed in the supreme courts of the same." Had the Rules of Decision Act coverea forms of "process" (or "procedure" as we would call it today), the Process Act would have been unnecessary. See also Wayman v. Southard, 23 U.S. (10 Wheat.) 1, 24 (1825) ("rule of decision" means "a rule to guide the Court in the formation of its judgment; not one for carrying that judgment into execution"). But cf. Westen \& Lehman, supra note 7, at 366 n.165 (suggesting that although this may have been the original meaning of "rules of decision," the meaning "changed" when Congress replaced the Conformity Act, 17 Stat. 197 (1872), successor to the Process Act, with the Rules Enabling Act, 48 Stat. 1064 (1934) (codified at 28 U.S.C. $\S 2072(1982))$ ).

144 I discuss further what constitutes a "rule of decision" infra note 200. 
such as the Constitution and federal statutes, or on the formulation of procedural or housekeeping rules for the governance of litigation in federal courts. If this were the end of the matter, our federal system might be able to carry on. With respect to one type of federal common law-the creation of implied rights of action-the Supreme Court has recently adopted a view of the powers of federal courts that focuses on specific legislative intent. ${ }^{145}$ Indeed, in diversity cases, the Court has indicated an even narrower role for federal common law, suggesting that application of a federal common law procedural rule could be barred if it would have a substantial impact on the plaintiff's choice of a forum. ${ }^{146}$

Nevertheless, there are reasons for being deeply troubled by the possibility that any lawmaking by federal courts is illegitimate unless the courts are enforcing the specific intentions of the draftsmen of authoritative texts or formulating housekeeping rules. One problem concerns "gaps" that appear in authoritative texts, which a court must "fill" before it can do its job of deciding cases. Another problem concerns textual provisions that are so broad or "open-textured" that something more than conventional interpretation may be required before a court can apply them.

Gaps often occur in authoritative texts, not only in the sense of ambiguous or inconsistent provisions (which generally present nothing more than particularly difficult problems in discerning specific intent), but also as a result of the draftsmen's inattention to issues that arise as an inevitable consequence of a statutory scheme. ${ }^{147}$ When a federal court encounters a gap in this latter sense and can find no indicia of specific intent to fill it, the federalism principle and the Rules of Decision Act would appear to require that the court adopt relevant state law as the rule of decision. This may frequently be a satisfactory solution, as in cases where Congress fails to specify a statute of limitations for a federal cause of action. ${ }^{148}$ In other cases, however, there may be no relevant state law, and unless the court could make law it would have

145 See, e.g., Transamerica Mortgage Advisors v. Lewis, 444 U.S. 11, 15-16 (1979) ("[W]hat must ultimately be determined is whether Congress intended to create the private remedy asserted . . . ."); Touche Ross \& Co. v. Redington, 442 U.S. 560, 578 (1979) (“The ultimate question is one of congressional intent . . ..").

146 Hanna v. Plumer, 380 U.S. 460, 469 (1965) (dictum).

147 See, e.g., Chevron Oil Co. v. Huson, 404 U.S. 97, 101 (1971), for use of "gap filling" terminology in this latter sense. Cf. Friendly, The Gap in Lawmaking-Judges Who Can't and Legislatures Who Won't, 63 Colum. L. Rev. 787 (1963) (using "gap" in a broader sense to include vague and ambiguous statutory provisions).

148 See, e.g., UAW v. Hoosier Cardinal Corp., 383 U.S. 696, 701-04 (1966); McCluny v. Silliman, 28 U.S. (3 Pet.) 270, 276-77 (1830). 
to leave the gap unfilled. ${ }^{149}$ Furthermore, there will be cases in which the adoption of state law as a rule of decision might undermine federal policies articulated elsewhere in the legislative scheme. ${ }^{150}$ In such cases, inability to impose a federal common law rule could frustrate specifically intended federal policies.

Another problem has to do with the interpretation of broad, vague, or open-textured provisions, of which the Bill of Rights presents a conspicuous, but not by any means the only, example. One school of thought contends that provisions such as these, no less than textual provisions that are ambiguous or contradictory, must be interpreted by searching for the specific intentions of the enacting body. ${ }^{151}$ Another school of thought rejects this approach, in part because the very decision by the enacting body to employ broad or vague language suggests that it did not have (or perhaps could not agree upon) a set of specific intentions. ${ }^{152}$ The intention of the enacting body may have been to have no specific intentions at all and to leave the matter for future determination by courts. The Supreme Court has wavered between these extremes. When confronted with broad or vague textual language, the Court sometimes consults historical materials in order to discern the specific intentions of the enacting body, ${ }^{163}$ and sometimes ignores evidence of specific intentions or declares that such evidence cannot be con-

149 In Campbell v. Haverhill, 155 U.S. 610 (1895), for example, Congress had failed to specify a statute of limitations for patent infringement, an exclusively federal cause of action. The Court held, properly enough, that in these circumstances the Rules of Decision Act required that relevant state law be applied. Since the action was exclusively federal, however, there was no directly relevant state statute of limitations. The defendant accordingly argued that this meant there was no state law to "apply," and thus that no limitations period governed the action. The Court did not respond adequately to this contention but simply concluded that the state statute of limitations for actions in tort was close enough to fill the gap. Id. at 614-15.

${ }_{150}$ See, e.g., Occidental Life Ins. Co. v. EEOC, 432 U.S. 355, 366-72 (1977). In Occidental, the Court refused to apply a one-year state statute of limitations for a federal cause of action in circumstances where this might interfere with investigation and conciliation efforts required by the federal statute. The Court's rationale was essentially that of preemptive lawmaking, discussed infra notes 155-74 and accompanying text.

${ }^{151}$ See, e.g., R. Berger, supra note 9, at 363-72; Bork, Neutral Principles and Some First Amendment Problems, 47 IND. L.J. 1, 17 (1971).

152 See, e.g., Karst, The Supreme Court, 1976 Term-Foreword: Equal Citizenship Under the Fourteenth Amendment, 91 HaRv. L. REv. 1, 17 (1977) (the choice made by the framers to "cast the [fourteenth] amendment in general terms . . gave the principle of equal citizenship its capacity to grow").

${ }^{163}$ See, e.g., Ruckelshaus v. Sierra Club, 103 S. Ct. 3274, 3278-81 (1983) (examining legislative history of $\S 307$ (f) of the Clean Air Act to determine meaning of statutory grant of attorney's fees "whenever . . . such an award is appropriate"); Minneapolis Star \& Tribune v. Minnesota Comm'r of Revenue, 103 S. Ct. 1365, 1371 n.6 (1983) (discussing the use of the intent of the framers of the first amendment). 
sidered dispositive. ${ }^{154}$ If a strict application of the internal norm represented a complete account of the lawmaking powers of federal courts, then the latter sort of cases-those that ignore or do not consider dispositive evidence of the specific intentions of the enacting body - would have to be regarded as illegitimate.

The internal norm of legitimacy that I have described is, however, capable of generating more than the conclusion that federal courts must confine themselves to searching for the specific intentions of the enacting body and fashioning procedural or housekeeping rules. It will also justify the creation of federal common law pursuant to what I will call the doctrines of "preemptive" and "delegated" lawmaking. These doctrines are not themselves elements of the internal norm of legitimacy but can be logically derived from that norm. Although they have not been recognized by name, there is substantial support for them in the case law ${ }^{155}$ and commentary. ${ }^{156}$ The Supreme Court has in effect recognized the doctrines of preemptive and delegated lawmaking on occasions when it has been the most self-consciously aware of the problems of lawmaking by federal courts, namely when it is asked to fill in a gap or to supplement a federal statutory scheme. ${ }^{157}$ What the Court has failed to see, however, is that these doctrines are equally relevant to other forms of federal common law and can be used, in conjunction with the conclusions derived from the discussion of

154 See, e.g., Brown v. Board of Educ., 347 U.S. 483, 492 (1954) (“[W]e cannot turn the clock back to 1868 when the [fourteenth] Amendment was adopted . . . ."); Home Bldg. \& Loan Ass'n v. Blaisdell, 290 U.S. 398, 442-43 (1934) (statement that Constitution must mean today only what it meant to framers in their time "carries its own refutation").

185 See, e.g., Texas Indus. v. Radcliff Materials, Inc., 451 U.S. 630, 640 (1981); Northwest Airlines v. Transport Workers Union, 451 U.S. 77, 95 (1981).

${ }^{158}$ For commentary recognizing something akin to what I call preemptive lawmaking, see David Currie, Federal Courts 436 (3d ed. 1982); Hill, supra note 23, at 1026-30; Monaghan, supra note 12, at 12; Note, Federal Courts, supra note 4, at 1089-94. For commentary recognizing some variant of delegated lawmaking, see G. CALABRESI, supra note 10, at 114-17; Easterbrook, supra note 33, at 539; Karst, supra note 152, at 17; Sandalow, supra note 20, at 1051-52; Note, Federal Common Law, supra note 4, at 1522-23.

${ }^{187}$ In Texas Indus. v. Radcliff Materials, Inc., 451 U.S. 630 (1981), the Court had this to say about the circumstances in which it is appropriate for federal courts to create common law rules of decision:

There is, of course, "no federal general common law." Nevertheless, the Court has recognized the need and authority in some limited areas to formulate what has come to be known as "federal common law." These instances are "few and restricted," and fall into essentially two categories: those in which a federal rule of decision is "necessary to protect uniquely federal interests," and those in which Congress has given the courts the power to develop substantive law.

$I d$. at 640 (citations omitted). The Court's two "exceptions" to the general proposition that common lawmaking by federal courts is illegitimate correspond essentially to what I term preemptive and delegated lawmaking. 
the internal norm of legitimacy, to develop a general theory of federal common law.

\section{A. Preemptive Lawmaking}

Preemptive lawmaking may be invoked when a court, although it can discern no specific intention on the part of the enacting body with respect to the question before it, finds that the adoption of state law as the rule of decision would unduly frustrate or undermine a federal policy as to which there is a specific intention on the part of the enacting body. In effect, the court finds that some federal policy specifically intended by an enacting body "preempts" the application of state law to some collateral or subsidiary point about which the enacting body has been silent. Here, however, rather than simply ignoring state law, as would be done in an ordinary preemption case, the court goes on to fashion a federal rule of decision to effectuate the enacting body's intent. Preemptive lawmaking can thus be regarded as a form of textual interpretation, but one that is distinctly different from "interpretation" in the conventional sense of searching for the specific intentions of the enacting body. ${ }^{158}$ When a court engages in preemptive lawmaking, it still may be said to be carrying out the original intentions of the enacting body - not, however, by directly applying the specific intentions of the draftsmen, but by asking what collateral or subsidiary rules are necessary in order to effectuate or to avoid frustrating the specific intentions of the draftsmen.

Examples of this type of federal common law are quite common, but Farmers Educational \& Cooperative Union v. WDAY, Inc. ${ }^{159}$ provides a particularly good illustration. Congress, as part of the Federal Communications Act, required licensed radio and television stations to provide equal time to candidates for political office and expressly forbade such stations to censor any of the ma-

${ }^{158}$ One branch of conventional preemption doctrine is directly concerned with ascertainment of congressional intent. As the Court has put it, "If Congress evidences an intent to occupy a given field, any state law falling within that field is preempted." Silkwood v. Kerr-McGee Corp., 104 S. Ct. 615, 621 (1984) (emphasis added). As I use the term, however, preemptive lawmaking is concerned more with the set of phenomena covered by the second branch of traditional preemption doctrine: "when it is impossible to comply with both state and federal law . . . or where the state law stands as an obstacle to the accomplishment of the full purposes and objectives of Congress." Id.; see also Pacific Gas \& Elec. v. State Energy, Resources, Conservation \& Dev. Comm'n, 461 U.S. 190, 204 (1983); Fidelity Fed. Sav. \& Loan v. de la Cuesta, 458 U.S. 141, 153 (1982).

159360 U.S. 525 (1959). 
terial broadcast under the equal time provision. ${ }^{160}$ The Act contained no provision immunizing licensees from state actions for defamation occurring in the course of such broadcasts. Nevertheless, when North Dakota sought to apply its libel laws to a station for broadcasting allegedly defamatory utterances by a political candidate invoking the equal time provision, the Supreme Court held that immunity would be inferred as a matter of federal common law. Any other rule, the Court said, would "sanction the unconscionable result of permitting civil and perhaps criminal liability to be imposed for the very conduct the statute demands of the licensee." "161 Indeed, the Court went on, "if a licensee could protect himself from liability in no other way but by refusing to broadcast candidates' speeches, the necessary effect would be to hamper the congressional plan to develop broadcasting as a political outlet . . . ."162 In short, because the state rule of decision (no immunity) would frustrate the specifically intended policy of promoting the use of broadcast facilities as political platforms, preemption of that rule-or, what was really the same thing, creation of a federal common law immunity - was required. ${ }^{163}$

Is the concept of preemptive lawmaking consistent with the internal norm of legitimacy? I believe it is, provided that federal courts are scrupulous about confining such lawmaking to cases where it is truly necessary either to oust state law or to supplement federal law in order to protect specifically intended federal policies. Suppose that a federal court has correctly determined that a particular exercise in preemptive lawmaking, such as that in $W D A Y$, is required in order to effectuate a policy specifically intended by Congress. In that event, such lawmaking would not violate the federalism principle, because it would be designed to vindicate a policy adopted by Congress in the exercise of one of its enumerated powers and thus, by hypothesis, "acquiesced" in by the states. Such lawmaking would also be consistent with the principles of separation of powers and electoral accountability: the court would simply be giving effect to policies specifically intended by Congress, the popularly accountable branch charged with the lawmaking function. Finally, such lawmaking would be authorized by the

18047 U.S.C. § $315(\mathrm{a})(1982)$.

161360 U.S. at 531.

162 Id. at 534-35.

${ }_{163}$ See also Howard v. Lyons, 360 U.S. 593, 597 (1959) (federal common law immunity governs suits for defamation brought against federal officials acting in official capacity); Barr v. Matteo, 360 U.S. 564, 569 (1959) (same). 
Rules of Decision Act, which provides that state law is to supply the rule of decision "except where the Constitution or treaties of the United States or Acts of Congress otherwise require . . . ." When application of state law would frustrate a specifically intended constitutional or congressional policy, "the Constitution or Acts of Congress 'require' otherwise than that state law govern of its own force."164

The difficulty with preemptive lawmaking is not that it is inconsistent in theory with the four principles that restrain lawmaking by federal courts, but rather that it is easily subject to abuse. The most obvious form of abuse occurs when the federal policy requiring preemption of state law is merely asserted to exist and is not grounded in the specific intentions of the enacting body. The case of Clearfield Trust Co. v. United States, ${ }^{165}$ for example, can be read as a case of preemptive lawmaking where the asserted federal interest was in avoiding the higher administrative costs of having "identical transactions subject to the vagaries of the laws of the several states." ${ }^{168}$ This could, of course, be a legitimate federal concern. But the Court cited no evidence for the proposition that Congress was anxious to minimize the costs to the United States in commercial-paper transactions at the expense of private bank endorsers (who would incur higher administrative costs by having commercial-paper transactions "subject to the vagaries" of federal or state law, depending on the status of the issuer of the check). ${ }^{167}$ The Court thus ignored the need to ground federal policy in the specific intentions of Congress. If the policy is not so grounded, then the states cannot be deemed to have "acquiesced" in it, the elected representatives in Congress and the President will not have passed upon it, and it cannot be said to be "required" by the Constitution or laws of the United States.

A second and more subtle danger occurs when the federal policy that is said to require preemption of state law (or supplementation of federal law) is derived not from the specific intentions of the enacting body but from some set of higher-order "values" or "background understandings" that the enacting body is supposed to have embraced. ${ }^{168}$ The problem here is that the language and

184 United States v. Little Lake Misere Land Co., 412 U.S. 580, 592-93 (1973).

185318 U.S. 363 (1943).

${ }^{188}$ Id. at 367.

${ }^{187}$ See Friendly, supra note 4, at 410; Mishkin, supra note 4, at 830-32.

${ }_{188}$ This is essentially the escape route from the separation-of-powers principle urged by Stewart and Sunstein: "When courts apply or interpret a statute, they must look to general background understandings as a basis for identifying the norms-sometimes hypostatized as 
legislative history of a text are usually consistent with more than one asserted "background understanding." In selecting one "background understanding" out of several possible candidates, the court may thus be substituting its own conception of public policy for that of the enacting body. ${ }^{169}$

United Steelworkers $v$. Weber ${ }^{170}$ illustrates the dangers inherent in this approach. The issue was whether an affirmative-action program voluntarily adopted as part of a collective-bargaining agreement violated the provision of Title VII that makes it unlawful to discriminate because of race against any individual with respect to employment. ${ }^{171}$ The Supreme Court conceded that the affirmative-action program fell within the literal language of the Act's proscription ${ }^{172}$ but carved out an exception for affirmativeaction programs designed to assist blacks. This federal common law exception was required, the Court reasoned, in order to effectuate the overriding purpose or "spirit" of the Act, which the Court said was to assist blacks in the job market. ${ }^{173}$ The problem with this approach is that the language and legislative history of the Act are also consistent with other descriptions of its overriding "spirit." For example, the purpose could just as easily have been to create a color-blind system of equal employment opportunity for all individuals regardless of their race. ${ }^{174}$ The invocation of a selected higher-order "spirit" or "background understanding" as a basis for preemptive lawmaking thus may have allowed the Court to substitute its own set of values for those agreed upon by the legislature, thereby violating the principles of federalism, separation of powers, and electoral accountability and the Rules of Decision Act.

'legislative intent'-that underlie the statute." Stewart \& Sunstein, Public Programs and Private Rights, 95 HARv. L. REv. 1193, 1231 (1982).

${ }^{188}$ See Chevron, U.S.A., Inc. v. Natural Resources Defense Council, Inc., $104 \mathrm{~S}$. Ct. 2778, 2793 (1984) ("responsibilities for assessing the wisdom of . . . policy choices and resolving the struggle between competing views of the public interest are not judicial ones"); Easterbrook, supra note 33, at 545-46 ("judicial pursuit of the 'values' or aims of legislation is a sure way of defeating the original legislative plan"); Munzer \& Nickel, supra note 15, at 1032-33 (discussing objections to interpreting Constitution through appeal to "very broad intent of the framers").

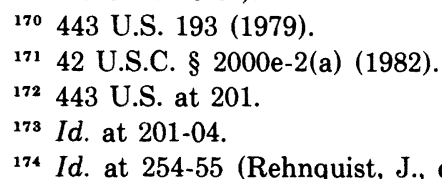
The Judicial Abrogation of the Antidiscri The Judial Abrogation of the Antidiscrimination Standard in Employment, 47 U. CHI. L. goal of Title VII). 


\section{B. Delegated Lawmaking}

Delegated lawmaking, in contrast to preemptive lawmaking, may be invoked where "Congress has given the courts the power to develop substantive law." ${ }^{175}$ In other words, delegated lawmaking takes place when Congress or the framers of the Constitution have conferred power on the federal courts to fashion federal rules of decision in order to round out or complete a constitutional or statutory scheme. Delegated lawmaking can also be said to entail an originalist mode of textual "interpretation," but in a different sense than either conventional interpretation or preemptive lawmaking does. Here, the court interprets the text to mean that the enacting body specifically intended that the relevant legal norms in a specific area are to be developed by the federal courts in accordance with the incremental decisionmaking process of the common law.

The leading case applying the concept of delegated lawmaking is Textile Workers Union v. Lincoln Mills, ${ }^{176}$ although it is doubtful that the concept was invoked in that case in a manner consistent with the internal norm of legitimacy. Section 301(a) of the Labor Management Relations Act provides for federal district court jurisdiction over "[s]uits for violation of contracts between an employer and a labor organization . . . in an industry affecting commerce . . . ."177 Based on "a few shafts of light"178 in the legislative history, the Court held that this provision was not merely a grant of jurisdiction but that it also "authorize[d] federal courts to fashion a body of federal law for the enforcement of these collective bargaining agreements . . . "178 The Court's handling of the legislative history was severely criticized by the dissent ${ }^{180}$ and, subsequently, by commentators. ${ }^{181}$ Apart from this problem, however, the decision is generally taken to have established the principle that it is within the power of Congress to delegate lawmaking

175 Texas Indus. v. Radcliff Materials, Inc., 451 U.S. 630, 640 (1981).

178353 U.S. 448 (1957).

17729 U.S.C. $\S 185(\mathrm{a})$ (1982).

178353 U.S. at 452.

179 Id. at 451.

${ }^{180}$ Id. at 460-64 (Frankfurter, J., dissenting); see also Association of Westinghouse Salaried Employees v. Westinghouse Elec. Corp., 348 U.S. 437, 441-49, 452-59 (1955) (plurality opinion by Frankfurter, J.) (dictum) (§ 301(a) provides jurisdiction only and does not authorize federal courts to make substantive law).

181 See, e.g., Bickel \& Wellington, Legislative Purpose and the Judicial Process: The Lincoln Mills Case, 71 Harv. L. Rev. 1, 36-37 (1957); Note, Federal Common Law, supra note 4 , at $1532-33$. 
power to the federal courts.

To what extent is delegated lawmaking consistent with the internal norm of legitimacy? Delegated lawmaking can be reconciled with the norm, provided that two requirements are satisfied: first, that the enacting body specifically intended to delegate lawmaking power to the federal courts, and second, that the textual provision that is said to give rise to the delegation circumscribes or "frames" with reasonable specificity the area in which judicial lawmaking is to take place. ${ }^{182}$ If the delegation is specifically intended and the area of delegation is reasonably circumscribed, then the states, through their representatives in Congress (or through the process of constitutional ratification), will have been put on notice of the delegation and may be presumed to have "acquiesced." Moreover, if the delegation is both intended and reasonably circumscribed, then the electorally accountable bodies will have knowingly relinquished legislative power to the federal courts in a particular area. Thus, when a delegation of lawmaking power satisfies these criteria, it does not violate the principles of federalism, separation of powers, or electoral accountability. Finally, such a delegation would appear to be consistent with the Rules of Decision Act. If the delegation is specifically intended, then the Constitution or an Act of Congress can be said to "provide" for the application of federal common law rather than state law.

182 The important point is not that the delegation tell the courts how to exercise their discretion, but that it indicate what sorts of issues the courts have discretion to decide. $C f$. Schauer, supra note 15, at 828 ("[W]e might do best to look at constitutional language as . . a blank canvas. We know when we have gone off the edge of the canvas even though the canvas itself gives us no guidance as to what to put on it."). In this regard, I view the requirement that the area of delegation be circumscribed with reasonable specificity to be more restrictive than the test applied in assessing the constitutionality of delegations to the executive branch, at least as that test has been applied in practice. The Supreme Court has held that a delegation to an executive-branch or independent agency must be based on an "intelligible principle" or ascertainable standard. See supra note 86 . But the courts have accepted virtually any general verbal formula as sufficient to satisfy this test. See, e.g., United States v. Southwestern Cable Co., 392 U.S. 157 (1968) (upholding FCC's authority to issue "such rules and regulations . . . not inconsistent with law" as "public convenience, interest or necessity requires"). The test for sustaining a delegation to the judicial branch, as I view it, would require enough specificity to put the members of the enacting body and the public on notice as to the scope or extent of the delegation of legislative authority; in other words, no one should be able to claim surprise as to the sorts of issues subsequently governed by federal common law. This more stringent standard is justified because executive-branch and independent agencies are accountable, at least indirectly, to the President, and the President is elected. Thus, executive-branch lawmaking is less in tension with the norms of federalism and electoral accountability than is judicial lawmaking. Furthermore, delegated lawmaking by administrative agencies is subject to the check of judicial review; delegated lawmaking by courts is not. It may also be that the test for assessing delegations to the executive branch is simply too lax. 
Delegated powers of lawmaking can be either express or implied. Express delegation of lawmaking authority to federal courts is rare. When it occurs, the only question that arises is whether the enacting body has framed the area in which the delegation has taken place with enough specificity to notify the states and electorally accountable bodies about the sorts of issues as to which lawmaking authority has been transferred to federal courts. An example of expressly delegated lawmaking that satisfies this criterion is Rule 501 of the Federal Rules of Evidence, which provides that in federal-question cases "the privilege of a witness, person, government, State, or political subdivision thereof shall be governed by the principles of the common law as they may be interpreted by the courts of the United States in the light of reason and experience." ${ }^{183}$ The intent to delegate is unmistakable, and the area of testimonial privilege is well enough defined that the states and Congress should have been aware of the sorts of issues that would henceforth be governed by federal common law.

Implied delegated lawmaking is much more common and gives rise to two questions: (1) whether the delegation is sufficiently circumscribed, and (2) whether a delegation was intended by the enacting body in the first place. What sort of evidence is sufficient to establish that the enacting body has implicitly delegated lawmaking power to federal courts? Although the answer no doubt depends on a variety of factors, it is possible to identify at least some general guidelines that can raise rebuttable presumptions of intent in this area.

First, the grant of federal jurisdiction, in itself, should not be considered sufficient to establish an intention to delegate lawmaking power. As the example of diversity jurisdiction suggests, Congress may confer jurisdiction on federal courts for reasons unrelated to any desire to avoid, or to create an alternative to, adjudication of the controversy under state law. The same could be said of the conferral of jurisdiction over suits involving the United States as a party, ${ }^{184}$ suits between states under the Supreme Court's original jurisdiction, ${ }^{185}$ and suits brought under section

${ }^{183}$ FED. R. EvID. 501. This Rule was enacted by Congress itself in lieu of a provision, proposed by the Advisory Committee and approved by the Supreme Court, enumerating specific privileges. See Act of Mar. 30, 1973, Pub. L. No. 93-12, 87 Stat. 9 (1973) (suspending the effectiveness of the Rules of Evidence transmitted to Congress by the Chief Justice); Act of Jan. 2, 1975, Pub. L. No. 93-595, 88 Stat. 1926, 1933-34 (1975) (congressional enactment of Rules of Evidence including current Rule 501).

18428 U.S.C. $\S \S 1345,1346$ (1982).

${ }^{185}$ Id. $\S 1251(\mathrm{a})$. 
301(a) of the Labor Management Relations Act. ${ }^{186}$ The primary motivation for conferring federal jurisdiction in each of these contexts was to avoid parochialism or bias on the part of state courts, not to oust or preempt the application of state law. ${ }^{187}$ Of course, it may be that in some of these contexts the application of state law would undermine or prejudice specifically intended federal policies. In such cases, however, preemptive lawmaking would generally provide an adequate justification for the creation of federal common law. ${ }^{188}$ But the grant of federal jurisdiction, without more, should not be thought to constitute a grant of delegated lawmaking power.

On the other hand, if in addition to granting jurisdiction to the federal courts, the enacting body adopts a broad legal standard that federal courts are directed to apply in resolving controversies, this may well support an inference of a delegation. Of course, virtually every enactment will require that courts exercise some discretion in applying the text to particular facts. But there is a category of provisions that are so vague and general that further "interpretation" is necessary before the process of application can even begin. ${ }^{189}$ In this sort of case, the courts must develop rules that translate the general textual language into applicable law. Obviously, the legislative history and other sources should be consulted to determine whether the enacting body intended that a broad text be read in a specific way. But absent any guidance from the enacting body, the courts can assume in such circumstances that they have been given power to construe the language in the manner they deem most congruent with the general purposes of the enactment.

A second and related set of circumstances that may support

18829 U.S.C. § 185(a) (1982).

187 See Guaranty Trust Co. v. York, 326 U.S. 99, 111 (1945) ("Diversity jurisdiction is founded on assurance to nonresident litigants of courts free from susceptibility to potential local bias.").

${ }^{188}$ The cases arising after Lincoln Mills under section 301(a) of the Labor Management Relations Act, 29 U.S.C. $§ 185$ (a) (1982), illustrate this point. Without ever officially having abandoned the delegated lawmaking rationale of Lincoln Mills, the Court has tended to fashion a federal rule only when a uniform rule is considered necessary, see, e.g., Local 174, Teamsters v. Lucas Flour Co., 369 U.S. 95, 102-04 (1962), and to adopt state rules otherwise, see, e.g., UAW v. Hoosier Cardinal Corp., 383 U.S. 696, 701-05 (1966) (adopting an appropriate state statute of limitations "as a matter of federal law"). In this area, therefore, the Court has in practice moved from delegated to preemptive lawmaking.

189 See Northwest Airlines v. Transport Workers Union, 451 U.S. 77, 95 (1981) ("Broadly worded constitutional and statutory provisions necessarily have been given concrete meaning and application by a process of case-by-case judicial decision in the commonlaw tradition."). 
an inference of delegation arises when, in addition to granting federal court jurisdiction, Congress adopts a legal standard that is borrowed from (or "codifies") the common law. Common law rules are judge-made rules, and if Congress has, in effect, federalized a body of common law principles, then it would seem that in all probability it intended that federal courts would continue to develop that body of law in the common law tradition. While the language of the text or the legislative history may suggest that Congress intended to "freeze" a body of common law at the time of enactment, the common law is widely understood to be an evolving and developing body of law. ${ }^{190}$ Absent some specific intention to preclude further development, therefore, adoption of common law precepts should be taken as an indication that the enacting body has delegated common law powers to federal courts.

The federal antitrust laws illustrate these rebuttable presumptions of delegated lawmaking. ${ }^{191}$ Both the Sherman Act and the Clayton Act expressly confer jurisdiction on federal courts to "prevent and restrain violations" of their provisions, ${ }^{192}$ and the Clayton Act authorizes private suits for damages under both Acts. ${ }^{193}$ In addition, both Acts direct the federal courts to apply vague and general legal standards drawn from the common law. For example, section 1 of the Sherman Act declares unlawful every contract, combination, or conspiracy "in restraint of trade or commerce."194 "Restraint of trade" is an exceedingly broad and general standard that could conceivably be read to prohibit all business contracts. In order to limit the Act in a meaningful way, therefore, federal courts have had to develop rules for differentiating between "lawful" and "unlawful" restraints. Furthermore, the concept of an unlawful restraint of trade had its origin in the common law. It thus seems reasonable to construe section 1 of the Sherman Act as federalizing the common law of unlawful restraints of trade ${ }^{195}$-in

190 See generally Edward Levi, An Introduction to Legal Reasoning 8-27, 27-57 (1948) (discussing the development of common law rules and the evolution of statutory interpretation).

191 I am by no means the first to make such an observation. See, e.g., Baxter, Separation of Powers, Prosecutorial Discretion, and the "Common Law" Nature of Antitrust Law, 60 TEx. L. REv. 661, 662-73 (1982); Easterbrook, Is There a Ratchet in Antitrust Law?, 60 TEX. L. Rev. 705, 706 (1982); Westen \& Lehman, supra note 7, at 333-34.

19215 U.S.C. $\S \S 4,25$ (1982).

193 Id. § 15.

194 Id. $\S 1$.

195 See Standard Oil Co. v. United States, 221 U.S. 1, 50-62 (1911); Northern Sec. Co. v. United States, 193 U.S. 197, 404 (1904) (Holmes, J., dissenting); United States v. Addyston Pipe \& Steel Co., 85 F. 271 (6th Cir. 1898), aff'd in part and modified in part on other 
other words, as reflecting a decision by Congress to transform a body of existing common law (much of which had been elaborated in state courts) into federal law and to authorize federal courts to continue to build upon that law through the incremental case-bycase process.

Indeed, although it is conventional to speak of cases arising under section 1 of the Sherman Act as "interpreting" the meaning of the Act, the Supreme Court has acknowledged that legal issues arising under section 1 are not resolved by searching for the specific intentions of the Congress of 1890 , but by a process of giving "shape to the statute's broad mandate by drawing on common-law tradition." ${ }^{196}$ Moreover, there is at least some direct evidence that Congress specifically intended that federal courts should proceed in this manner. Senator Sherman declared:

I admit that it is difficult to define in legal language the precise line between lawful and unlawful combinations. This must be left for the courts to determine in each particular case. All that we, as lawmakers, can do is to declare general principles, and we can be assured that the courts will apply them so as to carry out the meaning of the law as the courts of England and the United States have done for centuries. ${ }^{197}$

Section 1 of the Sherman Act is, therefore, a paradigm of implied delegated lawmaking. ${ }^{198}$

In sum, the doctrines of preemptive and delegated lawmaking are consistent with the central conclusion derived from the internal norm of legitimacy: courts must confine themselves to enforcing or interpreting the original meaning of federal texts. But they

grounds, 175 U.S. 211 (1899).

${ }^{108}$ National Soc'y of Professional Eng'rs v. United States, 435 U.S. 679, 688 (1978) (footnote omitted).

18721 Cong. Rec. 2460 (1890) (quoted in part in United States v. United States Gypsum Co., 438 U.S. 422,438 n.14 (1978)).

${ }^{198}$ Another prominent example of implied delegated lawmaking is the jurisprudence of "deceptive and manipulative" practices that has emerged under section 10(b) of the Securities Exchange Act of 1934, 15 U.S.C. § 78j(b) (1982).

[W]e would by no means be understood as suggesting that we are able to divine from the language of $\S 10(\mathrm{~b})$ the express "intent of Congress" as to the contours of a private cause of action under Rule 10b-5. When we deal with private actions under Rule 10b-5, we deal with a judicial oak which has grown from little more than a legislative acorn. Such growth may be quite consistent with the congressional enactment and with the role of the federal judiciary in interpreting it, but it would be disingenuous to suggest that either Congress in 1934 or the Securities and Exchange Commission in 1942 foreordained the present state of the law with respect to Rule 10b-5.

Blue Chip Stamps v. Manor Drug Stores, 421 U.S. 723, 737 (1975) (citation omitted). 
also represent extensions of that proposition. With preemptive and delegated lawmaking, we are still operating under an originalist mode of review, but the process is now derivative rather than direct. Preemptive lawmaking rests on the idea that federal courts can establish legal rule $X$, even where there is no specific intention that they do so, provided it can be shown that rule $X$ is necessary in order to avoid frustrating federal policy $Y$, as to which there is a manifestation of specific intent on the part of the enacting body. Delegated lawmaking rests on the notion that federal courts can establish rule $X$, even where there is no specific intent that they do so, provided it can be shown that the issue falls within a reasonably circumscribed class of issues as to which Congress or the fram$\mathrm{ers}^{199}$ specifically intended to delegate lawmaking power to the federal courts.

\section{The Legitimacy of Federal Common Law}

With the addition of preemptive and delegated lawmaking, we are now in a position to set forth a general analytical framework for resolving questions concerning the legitimacy of federal common law. In principle, any question involving the legitimacy of federal common law potentially entails four inquiries:

(1) Does the issue involve a "rule of decision"? 200 That

${ }^{198}$ In a later section of this article, I will consider whether the practice of constitutional lawmaking under the Bill of Rights can be justified as a form of implied delegated lawmaking. See infra notes 258-95 and accompanying text.

${ }^{200}$ The problem of defining the term "rule of decision" is pervasive. The phrase "rule of decision" was used by the first Congress in juxtaposition with the phrase "rule of process," see supra note 143 and accompanying text, and thus, as a first approximation, seems to have referred to "substantive," as opposed to "procedural," rules. This is helpful, but as Justice Frankfurter observed in Guaranty Trust Co. v. York, 326 U.S. 99, 108 (1945), "substance" and "procedure" mean different things in different contexts. For purposes of determining the common law powers of federal courts, the general distinction is between rules that fall within the province of the primary policymaking bodies-state legislatures and Congress-and rules of internal court governance or "housekeeping." See supra text accompanying notes $73,99-100,117,144$. Borrowing a suggestion from Professors Hart and Wechsler, see H. Hart \& H. Wechsler, The Federal Courts and the Federal System 678 (1953); see also Hart, supra note 4, at 508, Justice Harlan defined as "substantive" those rules that "would substantially affect those primary decisions respecting human conduct which our constitutional system leaves to state regulation." Hanna v. Plumer, 380 U.S. 460, 475 (1965) (Harlan, J., concurring). Substantive rules, in other words, guide the conduct of persons outside of the courtroom, before they are drawn into litigation. By negative implication, "procedural" rules are those that would not affect behavior in what Professor Hart has called "everyday, prelitigation life." Hart, supra note 4, at 508. This is consistent with the internal norm of legitimacy. Policymaking bodies-whether state legislatures, protected by the principle of federalism, or Congress, protected by the principle of separation of powers-should have no overriding interest in rules that do not affect "primary private activ- 
is, does it involve a question concerning the substantive rights and remedies available to parties, or does it involve merely a matter of judicial procedure or internal court governance? If the rule is a rule of decision in this sense, an issue of legitimacy is presented and it is necessary to turn to the remaining three inquiries to determine whether federal or state law supplies the rule. If the rule is not a rule of decision, then no issue of legitimacy is presented and the court is free to fashion a rule of federal common law, provided that such a rule is not inconsistent with the Constitution or any relevant acts of Congress.

(2) If the issue does involve a rule of decision, can an applicable federal rule be derived from conventional textual interpretation - that is, from a direct analysis of the specific intentions of the draftsmen of an authoritative federal text, such as the Constitution, treaties, or statutes of the United States?

(3) If the issue involves a rule of decision, and if conventional textual interpretation does not yield a rule, is a federal rule necessary in order to preserve or effectuate some other federal policy that can be derived from the specific intentions of the draftsmen of an authoritative federal text?

(4) Finally, if the issue involves a rule of decision, if conventional interpretation does not directly supply a rule, and if a federal rule is not necessary in order to preserve some other federal policy established by an authoritative text, is there evidence, based again on the specific intentions of the draftsmen of an authoritative federal text, that lawmaking power with respect to this issue has been delegated to federal courts in a reasonably circumscribed manner?

An affirmative answer to any one of questions (2) through (4) means that federal common law may legitimately supply the rule of decision. A negative answer to each of questions (2) through (4) means that the rule of decision must be supplied by relevant state law.

In this section I will attempt to show that the general framework set forth above provides both a critique of existing conceptions of the legitimacy of federal common law and a sound guide for future decisionmaking. To do so, I will survey three areas in which lawmaking by federal courts has been especially controver-

ity." Hanna v. Plumer, 380 U.S. at 475 (Harlan, J., concurring). 
sial. These are: (1) the authority of federal courts to create common law remedies, supplemental to those prescribed by Congress, to enforce rights founded in federal law; (2) the authority of federal courts to prescribe federal common law rules designed to further constitutional policies, with the understanding that the rules are subject to modification by congressional legislation (what Professor Henry Monaghan has called "constitutional common law"201); and (3) the authority of federal courts to engage in nonoriginalist judicial review. ${ }^{202}$

\section{A. Implied Remedies}

The Supreme Court has only recently recognized the problems of legitimacy presented when federal courts create federal remedies in addition to those authorized by Congress. With respect to constitutional rights, the legitimacy of judicially created remedies was first thoroughly debated in Bivens $v$. Six Unknown Named Agents of Federal Bureau of Narcotics. ${ }^{203}$ With respect to federal statutory rights, the legitimacy of additional court-created remedies was not fully brought into focus until Justice Powell filed his dissenting opinion in Cannon $v$. University of Chicago. ${ }^{204}$ Once raised, however, the question of "implied remedies," as they are usually called, has become a matter of controversy both within the Court and in the academic community. ${ }^{205}$

A significant feature of the implied-remedies cases is the

201 Monaghan, supra note 12 , at 3.

202 Other problems in federal common lawmaking, such as the authority of federal courts to adopt federal common law rules in diversity cases (the so-called Erie question) and the authority of federal courts to fill in gaps in federal statutes, are amenable to the same analysis. In the interest of not overburdening an already long article, these problems will be left for another day.

${ }^{203} 403$ U.S. 388 (1971); cf. Bell v. Hood, 327 U.S. 678, 684 (1946) (reserving the question of implied damages remedy).

204441 U.S. 677, 730-49 (1979) (Powell, J., dissenting).

${ }^{205}$ For a sampling of academic views, see Brown, Of Activism and Erie-The Implication Doctrine's Implications for the Nature and Role of the Federal Courts, 69 Iowa L. REv. 617, 644-54 (1984) (Erie and separation of powers create strong presumption against implied rights of action); Fischel, Secondary Liability Under Section 10(b) of the Securities Act of 1934, 69 CaLIF. L. REv. 80, 93-94 (1981) (appropriate to imply right of action for secondary liability only where specifically intended by Congress); Posner, Economics, Politics, and the Reading of Statutes and the Constitution, 49 U. CHI. L. REv. 263, 278-80 (1982) (appropriate to imply right of action under public-interest but not under interestgroup theory of legislation); Stewart \& Sunstein, supra note 168, at 1296-1316 (appropriate to imply right of action as a matter of federal common law to promote more efficient enforcement or to protect private entitlements). For thoughtful student work dealing with implied rights of action, see Comment, supra note 29; Comment, Private Rights of Action Under Amtrak and Ash: Some Implications for Implication, 123 U. PA. L. REv. 1392 (1975). 
Court's disparate treatment of constitutional and statutory rights. With respect to constitutional rights, the Court has declared that federal courts can decide whether or not to create an implied remedy in the manner of "a common-law tribunal." ${ }^{206}$ Specifically, the Court has said that an implied damages remedy is generally available unless the government can show "special factors counselling hesitation in the absence of affirmative action by Congress" ${ }^{207}$ or that "Congress has provided an alternative remedy which it explicitly declared to be a substitute for recovery directly under the Constitution and viewed as equally effective." ${ }^{208}$ Thus, there seems to be a presumption in favor of an implied remedy, and the burden is on Congress to negate such a presumption.

With respect to statutory rights, however, the Court has recently formulated a quite different standard. ${ }^{209}$ After adopting what amounted to a presumption in favor of implied remedies for statutory violations in J.I. Case Co. v. Borak, ${ }^{210}$ and then a fourpart balancing test in Cort $v$. Ash, ${ }^{211}$ the Court has now determined that the "central inquiry" in every case is whether "Congress intended to create, either expressly or by implication, a private cause of action." ${ }^{212}$ In other words, in the statutory area the Court has embraced a conception of the powers of federal courts that is essentially identical to the conclusion I derived from the internal norm before discussing the application of delegated or preemptive lawmaking: federal courts may enforce only the express terms of the text and the specific intentions of the enacting body. The Court has not satisfactorily explained, however, why its power to create constitutional remedies ought to differ so drastically from

${ }^{208}$ Bush v. Lucas, 103 S. Ct. 2404, 2411 (1983).

${ }^{207}$ Bivens v. Six Unknown Named Agents of Fed. Bureau of Narcotics, 403 U.S. 388, 396 (1971); see also Carlson v. Green, 446 U.S. 14, 18 (1980) (quoting Bivens).

${ }^{208}$ Carlson v. Green, 446 U.S. 14, 18-19 (1980) (citing Bivens).

209 The recent decision in Bush v. Lucas, 103 S. Ct. 2404 (1983), may, however, mark the beginning of a convergence in the Court's doctrine regarding constitutional and statutory remedies. The Court declined to recognize a Bivens remedy where Congress had erected an "elaborate, comprehensive scheme" of administrative remedies. Id. at 2415. This scheme, the Court found, was a "special factor counselling hesitation," although it contained no explicit ouster of a constitutional remedy. In the context of statutory remedies, the Court has similarly relied on the existence of "elaborate" congressional legislation to infer the absence of congressional intent to create an implied damages remedy. See, e.g., Middlesex County Sewerage Auth. v. National Sea Clammers Ass'n, 453 U.S. 1, 13-15 (1981).

${ }^{210} 377$ U.S. 426, 431-35 (1964) (where statutory purpose is to protect investors, judicial relief is available where necessary to further that purpose).

211422 U.S. 66, 78 (1975).

212 Touche Ross \& Co. v. Redington, 442 U.S. 560, 575 (1979). 


\section{its power to create statutory remedies. ${ }^{213}$}

Under the approach to lawmaking by federal courts that I have advocated, there is one general theory of legitimate federal common law. The analysis does not change depending on whether the right sought to be vindicated derives from the Constitution or from a federal statute or whether the relief sought is an injunction or damages. When a court is asked to grant a remedy not expressly authorized by any federal text, it should apply the four-part test set out above. ${ }^{214}$

Since the existence of particular remedies may have an impact on the way people or institutions behave, we may assume that the

${ }^{213}$ Indeed, both Bivens itself and the academic commentary on Bivens rely heavily on the Court's presumption in favor of implied statutory remedies evidenced in Borak. See Bivens, 403 U.S. at 397; id. at 402, 406-07, 410-11 (Harlan, J., concurring); Dellinger, Of Rights and Remedies: The Constitution as a Sword, 85 HARv. L. REv. 1532, 1540-43 (1972). The Court's subsequent disavowal of Borak thus would seem to call into question the doctrinal underpinnings of Bivens.

In Davis v. Passman, 442 U.S. 228 (1979), which was decided about the same time that the Court first adopted its "specific intentions" approach to statutory remedies, the Court sought to justify its divergent doctrine on the ground that "[s]tatutory rights and obligations are established by Congress, and it is entirely appropriate for Congress, in creating these rights and obligations, to determine in addition who may enforce them and in what manner." Id. at 241; see also id. at 252 n.1 (Powell, J., dissenting) (Court's interpretive latitude is greater under the Constitution than under statutes, and its responsibility to protect constitutional rights is greater than its responsibility to enforce congressionally created rights). On its face, this would appear to beg the question: even if Congress does not "create" constitutional rights and obligations, it doesn't necessarily follow that federal courts, rather than Congress, should be the primary agency to determine "who may enforce them and in what manner." The Court may have been suggesting, however, that judicial creation of implied constitutional remedies is justified because, realistically speaking, federal courts "create" those rights and obligations, and thus federal courts should also resolve questions about remedies. In other words, the Court may have been suggesting that judicial creation of constitutional remedies can be justified by the doctrine of delegated lawmaking. In order to sustain Bivens actions as a form of delegated lawmaking, however, one would have to show that the framers of the Constitution specifically intended to delegate power to the federal courts to fashion remedies for constitutional enforcement. As Davis itself acknowledged, power to define the scope of substantive rights is different from the power to define the range of remedies available to enforce those rights. See Davis, 442 U.S. at 239 n.18. Thus, a showing that the framers delegated lawmaking power to the courts with respect to the former would not necessarily support the finding that they had delegated lawmaking power with respect to the latter. But cf. Easterbrook, Substance and Due Process, 1982 Sup. Cт. REv. 85, 114 (rights and remedies are dependent variables: where Congress creates a right, it can control the scope of that right by controlling the remedy; where the Constitution creates a right, the Court reserves control over remedies). My view is that judicial development of substantive constitutional law should be justified as a form of delegated lawmaking, while judicial development of constitutional remedies (where other remedies are inadequate) should be justified as a form of preemptive lawmaking. See infra notes 218-24, 249-99 and accompanying text.

${ }^{214}$ See supra text accompanying note 200. 
availability vel non of a particular remedy is a "rule of decision"215 and that a problem of legitimacy is therefore presented. ${ }^{216}$ By definition, the remedy in question is not authorized by the text itself. The initial inquiry, therefore, must be to determine whether, despite its silence, the enacting body specifically intended that such a remedy be recognized. To be sure, "the legislative history of a statute [or constitutional provision] that does not expressly create or deny a private remedy will typically be equally silent or ambiguous on the question."217 Thus, as a general matter, it is unlikely that an examination of the structure and history of the enactment will yield evidence of a specific intent to create such a remedy. There may be rare cases where the history will reveal that the omission of a particular remedy was an oversight, or that the draftsmen believed that courts would recognize an implied remedy and hence that it was unnecessary to make such a remedy express. ${ }^{218}$ But for the most part, the techniques of conventional interpretation will not authorize judicial creation of remedies beyond those expressly provided by Congress.

At this point, however, the doctrine of preemptive lawmaking comes into play. Although at first blush it may seem odd to apply the concept of preemptive lawmaking in order to create additional remedies, the underlying rationale is essentially the same in this context as it is when a court finds it necessary to preempt or supplement state substantive rules in order to preserve federal statutory policies. If existing state and federal remedies are adequate to preserve a specifically intended federal right, then there is no justification for creating additional federal remedies. On the other hand, if state-created remedies, together with whatever federal remedies are specified by Congress, are insufficient to preserve a specifically intended federal right, then it is appropriate for federal courts to create additional remedies that will preserve that right.

Application of the doctrine of preemptive lawmaking can be illustrated with reference to the facts of Bivens. The question there, as seen by both the Second Circuit and the Supreme

215 See supra note 200.

218 See, e.g., Cannon v. University of Chicago, 441 U.S. 677, 746-48 (1979) (Powell, J., dissenting) (by creating a private right of action, the Court "extends its authority to embrace a dispute Congress has not assigned it to resolve").

217 Cannon v. University of Chicago, 441 U.S. 677, 694 (1979).

${ }^{218}$ See, e.g., Merrill Lynch, Pierce, Fenner \& Smith, Inc. v. Curran, 456 U.S. 353, 38182 (1982) (finding congressional intent based on statutory reenactment after lower courts had recognized implied right of action). 
Court, ${ }^{219}$ was whether a state cause of action for trespass and the federal exclusionary rule, taken together, were sufficient to redress an alleged violation of the plaintiff's fourth amendment rights, or whether a supplemental federal common law remedy in damages should also be created in order to vindicate those rights. The Second Circuit stated the correct standard: if state court remedies and the exclusionary rule would render the constitutional right a "mere form of words," then it would be necessary to create a federal remedy. ${ }^{220}$ In contrast, the Supreme Court, by suggesting that a federal remedy should be created even where it would not be necessary to preserve the right, ${ }^{221}$ enunciated a standard that sanctions illegitimate judicial lawmaking.

As should be apparent from the Bivens example, it is essential that a federal court, before engaging in preemptive lawmaking, first determine whether Congress or the framers specifically intended to create a federal right enforceable by judicial action. ${ }^{222}$

219 Bivens v. Six Unknown Named Agents of Fed. Bureau of Narcotics, 403 U.S. 388, 390-97 (1971); Bivens v. Six Unknown Named Agents of the Fed. Bureau of Narcotics, 409 F.2d 718, 725-26 (2d Cir. 1969).

${ }^{220} 409$ F.2d at 722-23. Whether the Second Circuit correctly applied this standard is another matter. Mr. Bivens was not tried for any offense after the allegedly illegal search, $409 \mathrm{~F} .2 \mathrm{~d}$ at 719 , and thus the exclusionary rule would be of no assistance to him. Moreover, since the search apparently occurred without warning, $i d$., there was no possibility of securing injunctive relief. For Mr. Bivens, therefore, it was "damages or nothing." 403 U.S. at 410 (Harlan, J., concurring). Consequently, the critical question was whether he had an effective action for damages under state law. Although the Supreme Court intimated that Mr. Bivens might be barred from bringing a state trespass action because of his "consent" to the search, 403 U.S. at $394-95$, it does not appear that the record was sufficient to allow the courts to resolve this question.

The conventional argument against reliance on state tort remedies for constitutional violations is that recovery against individual state officers will be inadequate to induce a plaintiff to file suit. See, e.g., Foote, Tort Remedies for Police Violations of Individual Rights, 39 MinN. L. REv. 493, 499 (1955). If this means that state law imposes barriers that prevent full compensation of the plaintiff, this might justify the creation of a Bivens action as an alternative means of constitutional enforcement. If, however, it means that constitutional violations will often result in monetary awards too small to merit the expense of litigation, creation of a federal remedy will do nothing to change the matter and would thus be illegitimate.

${ }^{221}$ Rejecting the Second Circuit's suggestion that creation of a damages remedy would be proper only if necessary to prevent the fourth amendment from becoming a "form of words," the Court said that the question was whether damages is "a particular remedial mechanism normally available in the federal courts." Bivens, 403 U.S. at 387. Later decisions then developed the two-part inquiry summarized supra notes 206-08 and accompanying text.

${ }^{222}$ Given the sparse legislative history of the Bill of Rights, it is difficult to know for certain whether the framers intended that these guarantees would be judicially enforceable. I argue below that there is circumstantial evidence that they did. See infra notes 275-73 and accompanying text. The contemporary Supreme Court entertains no doubts on this score. See, e.g., Davis v. Passman, 442 U.S. 228, 241 (1979) ("the judiciary is clearly discernible as 
The possibility that Congress or the framers intended a provision to be "merely precatory," 223 in the sense that it would not be enforceable by judicial action, should not be dismissed as unthinkable. Indeed, congressional failure to specify "adequate" remedies should be taken as one piece of evidence that the provision was intended to be precatory in this sense. ${ }^{224}$ Nevertheless, it should be possible to overcome the inference from silence with evidence that the draftsmen specifically intended to create a judicially enforceable right, in which case creation of a federal common law remedy may be necessary to carry out that intent.

The doctrine of preemptive lawmaking suggests that the Supreme Court has been at once too restrictive with respect to judicially created remedies for statutory violations and too expansive with respect to judicially created remedies for constitutional violations. By ignoring the possibility of preemptive lawmaking altogether in the statutory area, the Court has overlooked the fact that relegating a plaintiff to existing state and federal remedies could in some cases render federal rights a "mere form of words." On the other hand, by ignoring the essential predicate for preemptive lawmaking in the constitutional context-a finding that creation of a federal remedy is necessary in order to preserve a specifically intended federal right - the Court has authorized illegitimate judicial lawmaking. A recognition that judicial creation of remedies presents a problem in the legitimacy of federal common law would eliminate the unsound extremes of the Court's doctrine in both areas.

the primary means through which these [constitutional] rights may be enforced").

${ }^{223}$ Cf. Davis v. Passman, 442 U.S. 228, 242 (1979) ("[U]nless such rights are to become merely precatory, the class of those litigants who allege that their own constitutional rights have been violated . . . must be able to invoke the existing jurisdiction of the courts for the protection of their justiciable constitutional rights.").

224 See generally Easterbrook, supra note 213, passim (arguing that legal entitlements cannot be defined in isolation from the procedures supplied by Congress for their enforcement). An example of a federal statute that may well have been intended to be precatory in this sense is the National Environmental Policy Act of 1969, 42 U.S.C. $\S \S 4321,4331-4335$, 4341-4347, 4361 (1982). Although the courts have held that an implied right of action exists to enforce the Act by injunctions and declaratory judgments, see generally FrEDERICK ANDERSON, NEPA IN THE CourTs ch. 1 (1973), the absence of any provision in the original statute referring to judicial proceedings, and of any discussion of judicial enforcement in the legislative history, suggests that Congress may well have intended that the statute would not be enforced at the instance of private parties in judicial proceedings. See R. STEWART \& J. Krier, Environmental Law and Policy 743-44 (2d ed. 1978) (questioning whether the courts were intended to assume responsibility for implementing the statute). 


\section{B. Constitutional Common Law}

The question of the legitimacy of federal common law arises not only against a background of congressional lawmaking but also, as Bivens illustrates, in the context of policies derived from the federal Constitution. Two other areas in which federal common law intersects with the Constitution involve what Professor Henry Monaghan has called "constitutional common law"225 and what modern constitutional theorists call "nonoriginalist" judicial review. ${ }^{226}$ I will consider the first of these in this subsection and the second in the subsection that follows.

Monaghan defines constitutional common law as "a substructure of substantive, procedural, and remedial rules drawing their inspiration and authority from, but not required by, various constitutional provisions . . .."227 As examples of what he considers to be constitutional common law, Monaghan cites, inter alia, the dormant commerce clause cases, ${ }^{228}$ the fourth amendment exclusionary rule, ${ }^{229}$ and Miranda warnings. ${ }^{230}$ The principal virtue that Monaghan sees in constitutional common law is that such rules, being "inspired" but not "required" by the Constitution, may be overridden by Congress. ${ }^{231}$ Thus, constitutional common law enjoys a degree of flexibility that traditional, Marbury-style constitutional interpretation does not. Indeed, although he repeatedly acknowledges that constitutional common law presents a problem of legitimacy, ${ }^{232}$ Monaghan defends such law largely on the basis of its desirability or "utility." 233

Under the internal-norm analysis, a body of common law rules "inspired" but not "required" by the Constitution presents far more serious problems of legitimacy than Monaghan acknowledges. Such a body of law would violate the modern principle of federalism, since the states cannot be deemed to have acquiesced in "legislative rules" framed by federal courts. ${ }^{234}$ It would also violate the

225 Monaghan, supra note 12 , at 3.

${ }^{226}$ See, e.g., Brest, supra note 8, passim.

${ }^{227}$ Monaghan, supra note 12 , at 2-3.

${ }^{228}$ Id. at 15-16; see, e.g., Gibbons v. Ogden, 22 U.S. (9 Wheat.) 1 (1824).

228 Monaghan, supra note 12, at 3-10; see, e.g., Mapp v. Ohio, 367 U.S. 643 (1961).

${ }^{230}$ Monaghan, supra note 12, at 20-23; see, e.g., Miranda v. Arizona, 384 U.S. 436 (1966).

231 Monaghan, supra note 12 , at 3.

232 See, e.g., id. at 8, 12, 23.

${ }^{233}$ Id. at 23; cf. Schrock \& Welsh, supra note 39, at 1124 \& passim (arguing generally that Monaghan allows utility to substitute for legitimacy).

234 Monaghan concedes that the federalism objection has "considerable force," Monaghan, supra note 12 , at 35 , but he advances several reasons why he finds it ultimately 
principles of separation of powers and electoral accountability, since the Constitution confers authority to promulgate rules governing primary conduct on elected representatives in Congress, not the federal courts. ${ }^{235}$ And finally, the adoption of federal rules not specifically "required" by the Constitution or the statutes of the United States would transgress the Rules of Decision Act. ${ }^{236}$

Under the internal norm of legitimacy, federal courts should be empowered to fashion common law based on the Constitution in the same circumstances in which they would be empowered to fashion federal common law generally. When a rule of decision is involved, this means applying the techniques of conventional interpretation and the doctrines of preemptive and delegated lawmaking. With respect to the body of doctrine that Monaghan identifies as "constitutional common law," making supplies the theoretical justification missing from Monaghan's account. ${ }^{238}$ Constitutional common law also provides

\footnotetext{
"not decisive," id. at 38. First, he contends that there is "arguably a need for a uniform national definition of at least the significant dimensions of individual liberties having their source in the Federal Constitution," id. at 35-36, and that the Supreme Court has "special institutional competence" to formulate such rules, $i d$. at 36 . This line of reasoning appears to conflate the issues of legitimacy and utility. Moreover, it overlooks the possibility that the "dimensions" of provisions such as the Bill of Rights can be filled in, if at all, by delegated lawmaking. See infra notes 249-99 and accompanying text. Second, he notes that the "revisionary role of Congress provides a forum in which state interests may be recognized," Monaghan, supra note 12 , at 36 , an argument which overlooks the objections to congressional override as a basis for preserving fundamental constitutional norms, see supra notes 90-95 and accompanying text. Finally, Monaghan argues that the objection from federalism is mitigated by the "flexibility" of federal constitutional common law; while the Court may carve out a general principle of federal concern, it may allow the states the freedom to develop rules "consistent with underlying federal policies." Monaghan, supra note 12, at 37. Attractive as this flexibility may seem, it does not address the problem of legitimacy: it allows the Court to incorporate state law if useful but does not provide a rule for when the Court must or must not adopt state law. The doctrines of delegated and preemptive lawmaking do provide such a rule.

${ }^{236}$ Monaghan's only comment about separation of powers, at least as it relates to the division of functions between Congress and the courts, is that the possibility of congressional override of constitutional common law "vitiates" any such objection. Monaghan, supra note 12 , at 34 . The flaws in this line of reasoning have already been discussed. See supra notes 90-95 and accompanying text. His answer to the electoral-accountability objection is the same. See Monaghan, supra note 12, at 28 n.146.

${ }^{236}$ Monaghan's only comment concerning the Rules of Decision Act is an acknowledgment that, although the Act would permit federal common law to be applied when "state law is seen to be in material conflict with the policies of federal law," Monaghan, supra note 12 , at $12 \mathrm{n} .69$ (emphasis in original), it does not otherwise authorize federal common law. He does not explain how, given this acknowledgment, his version of constitutional common law can be reconciled with the Rules of Decision Act, except to note that the federal courts also frequently ignore this aspect of the Act. Id.

${ }^{237}$ Monaghan, supra note 12 , at 3.

${ }^{238}$ The Supreme Court has on several occasions applied something like preemptive law-
} 
an appropriate occasion to consider the circumstances in which Congress may override federal common law that is based on preemptive lawmaking.

Monaghan's constitutional common law is controversial because of an apparent paradox: rules of decision derived from the Constitution are supposed to control acts of Congress, yet constitutional common law supposedly can be modified, or even overridden, by congressional enactment. One example of congressional override identified by Monaghan occurs in the so-called dormant commerce clause cases. On several occasions when the Supreme Court has held state regulations unconstitutional as an undue burden on interstate commerce, Congress has responded by enacting legislation authorizing or approving the regulation in question, and on further review the Court has then upheld the state practice on the ground that it had been authorized or approved by Congress. ${ }^{238}$ In addition to these cases, Monaghan argues that certain constitutional remedies, such as the fourth amendment exclusionary rule ${ }^{240}$ and Miranda warnings, ${ }^{241}$ also fall into the class of constitutional common law subject to congressional override. ${ }^{242}$ In my view, only the doctrine of preemptive lawmaking offers a satisfactory theoret-

making in justifying the creation of federal common law under the Constitution. In addition to the issues previously mentioned in the text, I would include within this category the use of federal common law in resolving interstate boundary and water disputes, see, e.g., Hinderlider v. La Plata River \& Cherry Creek Ditch Co., 304 U.S. 92, 110 (1938), the federal common law of international relations, see, e.g., Banco Nacional de Cuba v. Sabbatino, 376 U.S. 398 (1964), and (perhaps) the federal common law of nuisance, see, e.g., Illinois v. City of Milwaukee, 406 U.S. 91 (1972).

239 See, e.g., Prudential Ins. Co. v. Benjamin, 328 U.S. 408, 426-27 (1946) (McCarranFerguson Act authorized states to regulate and tax insurance companies); Clark Distilling Co. v. Western Md. Ry., 242 U.S. 311, 321-25 (1917) (Webb-Kenyon Act left states free to regulate commerce in intoxicating liquors); see also White v. Massachusetts Council of Constr. Employers, Inc., 103 S. Ct. 1042, 1047 (1983) (dictum) (regulation of commerce promulgated by a city pursuant to terms of congressional grant of project funding does not violate commerce clause). It is also possible to read these cases as not involving any congressional "override" but merely as enforcing a single principle: states cannot regulate interstate commerce absent congressional consent. If Congress provides such consent where it was previously lacking, this does not call into question the Court's interpretation of the Constitution. Congress overrides the result in a particular case but does not challenge the constitutional rule. My analysis is valid whether or not Monaghan's characterization of the dormant commerce clause cases is correct.

${ }^{240}$ Monaghan, supra note 12, at 4-10 (citing United States v. Peltier, 422 U.S. 531, 53839 (1975); United States v. Calandra, 414 U.S. 338, 354 (1974)).

${ }^{241}$ Monaghan, supra note 12 , at 20 (citing Miranda v. Arizona, 384 U.S. 436, 467 (1966)).

${ }^{242}$ Other examples of constitutional common law Monaghan mentions include interstate boundary cases, "lineup" cases, and procedural due process cases. Monaghan, supra note 12 , at $14,20,24-26$. 
ical account of the apparent paradox of rules derived from the Constitution yet subordinate to the will of Congress.

Under the doctrine of preemptive lawmaking, federal courts may fashion federal common law rules whenever it is necessary to protect some policy specifically intended by the framers of an authoritative federal text. ${ }^{243}$ When this kind of common law is created, and Congress (or, for that matter, a federal agency or a state) subsequently enacts legislation that provides adequate protection for the text-based policy, then the federal common law rule is no longer "necessary" and should be deemed to have been displaced by the subsequent enactment. The logic of preemptive lawmaking therefore suggests that this branch of federal common law is subject to congressional override.

With respect to statutory common law, preemptive rules can be displaced in two circumstances: (1) when Congress passes a new statute that either expressly or implicitly evinces a specific intent to override an existing judicially created rule, or (2) when Congress (or another lawmaking body) enacts a law that provides an adequate substitute for a judicially created rule. The first circumstance covers cases in which the Court did not correctly perceive congressional policy; Congress may adjust the degree of protection to express its true intent. ${ }^{244}$ The second circumstance covers cases in which, although the Court correctly perceived congressional policy, Congress (or a federal agency or state lawmaking body) subsequently changes or supplements the law in such a way that the preemptive rule is no longer necessary. In such cases, the federal common law rule should be deemed overruled.

With respect to constitutional common law, however, preemptive rules cannot be overturned by mere congressional disapproval. The federal judiciary, not Congress, is the ultimate interpreter of the specific intentions of the framers of the Constitution and thus has the final say in determining what policies are reflected in that document. ${ }^{245}$ Nevertheless, congressional override should be permissible when Congress enacts a statute that affords an adequate

${ }^{243}$ See supra notes 158-74 and accompanying text.

${ }^{244}$ Cf. Arnett v. Kennedy, 416 U.S. 134, 155 (1974) (plurality opinion) (where Congress creates substantive right coupled with specific procedural protection of that right, the right is conditioned by the scope of the procedures); Easterbrook, supra note 213, at 114 (scope of congressionally created rights cannot be separated from scope of congressionally created remedies). But cf. Cleveland Bd. of Educ. v. Loudermill, 53 U.S.L.W. 4306, 4308 (U.S. Mar. 19, 1985) ("straightforward" rejection of Arnett plurality; right to due process confined by Constitution, not by legislature).

${ }^{245}$ Cooper v. Aaron, 358 U.S. 1, 18 (1958) (dictum). 
substitute for the constitutional common law rule. Since necessity is the foundation of preemptive lawmaking, the disappearance of necessity eliminates the foundation for the rule. Thus, Congress may override preemptive lawmaking based on the Constitution, but only if the federal courts independently conclude that Congress has enacted a statute that provides roughly the same degree of protection for constitutional policies as the federal common law rule. ${ }^{246}$

It follows that Monaghan is correct in identifying a body of federal common law based on constitutional policies that can, under certain circumstances, be overridden by Congress. But he fails to specify the principles necessary for the creation and displacement of such common law rules. Monaghan would apparently allow courts to create constitutional common law on utilitarian grounds, and he would apparently allow such rules to be displaced on mere congressional say-so. Under the doctrine of preemptive lawmaking, however, constitutional common law may be created only when it is necessary to protect a specifically intended constitutional policy, ${ }^{247}$ and, once created, the common law rule can be displaced only upon a finding by the courts that Congress has supplied an adequate substitute for the common law rule.

Obviously, the doctrine of preemptive lawmaking will often call for difficult exercises of judgment regarding the necessity for creation of federal common law rules and the adequacy of congressional substitutes. But the doctrine better explains and justifies the Court's decisions than does Monaghan's theory, which is con-

${ }^{246}$ For a similar conclusion, developed in the context of congressional override of Bivens actions, see Dellinger, supra note 213, at 1547-49.

247 Ordinarily, preemptive lawmaking is based on a judicial finding that a federal common law rule is required in order to preserve or effectuate some policy specifically intended by the enacting body. But there is no reason why preemptive lawmaking could not also be based on the need to preserve or effectuate policies articulated by federal courts pursuant to delegated lawmaking. In other words, there is no reason why preemptive lawmaking cannot "piggyback" on top of delegated lawmaking. This would appear to be what has happened with respect to most of the rules that Monaghan identifies as constitutional common law. One example is the application of the exclusionary rule to suppress evidence obtained from a warrantless wiretap. The determination that a warrantless wiretap is a "search" within the meaning of the fourth amendment is a product of delegated lawmaking. $C f$. Katz v. United States, 389 U.S. 347, 364-74 (1967) (Black, J., dissenting) (majority's conclusion that electronic eavesdropping is a "search" is an extension of Court's power not supported by specific intentions of the framers). Application of the exclusionary rule as a remedy to enforce this conclusion is a product of preemptive lawmaking. Given the logic of preemptive lawmaking, Congress can override the exclusionary rule (for example, by providing for an adequately protective administrative system of fines or tort remedies). Given the logic of delegated lawmaking, however, Congress cannot override the conclusion that a wiretap is a fourth amendment "search." See infra text accompanying note 257. 
stitutionally unprincipled, or the theory of Monaghan's critics, who insist that all constitutional rules must be derived from the specific intentions of the framers and, once derived, may never be set aside by any action short of constitutional amendment. ${ }^{248}$

\section{Nonoriginalist Judicial Review}

As we have just seen, the doctrine of preemptive lawmaking provides a theoretical justification for a body of judge-made law that derives its authority from the Constitution and yet is, under certain circumstances, subject to congressional override. But what about "ordinary" constitutional law, such as the now huge body of doctrine created by the Supreme Court under the Bill of Rights? Virtually all of this doctrine is federal common law, as I have defined that term, since it is not derived from anything on the face of the Constitution.

Some of the law that has been fashioned by the courts in the name of the Bill of Rights (or other constitutional provisions) is the product of a search for the specific intentions of the framers. Commentators generally agree that where constitutional lawmaking is a product of this sort of conventional interpretation, its legitimacy is not controversial. ${ }^{249}$ Most modern constitutional law, however, cannot be traced to the specific intentions of the framers. To take but one prominent example, the Court in Brown v. Board of Education ${ }^{250}$ disclaimed any reliance on the specific intentions of the framers of the fourteenth amendment. In approaching the problem of segregated schools, the Court announced, "we cannot turn the clock back to 1868 when the Amendment was adopted . . . ."251 Hence, the Court's conclusion that segregated schooling violates the equal protection clause did not rest-and indeed probably could not rest ${ }^{252}$-on conventional interpretation.

If decisions such as Brown cannot be sustained as conventional interpretation, neither can they be justified by the doctrine of preemptive lawmaking. Preemptive lawmaking requires a finding that a federal rule of decision is necessary in order to preserve

\footnotetext{
${ }^{248}$ See, e.g., Schrock \& Welsh, supra note 39 , at 1171-76.

24 See, e.g., M. PERRY, supra note 9, at 16.

280347 U.S. 483 (1954).

${ }^{251}$ Id. at 492.
}

${ }^{262}$ See generally R. BERGER, supra note 9, at 117-33 (arguing that the legislative history of the fourteenth amendment is inconsistent with an intent to prohibit segregation); Bickel, The Original Understanding and the Segregation Decision, 69 HaRv. L. Rev. 1, 64-65 (1955) (concluding that the framers did not expect the equal protection clause to forbid segregation). 
federal policies that were specifically intended by the enacting body - in this case, the framers of the Constitution. ${ }^{253}$ There is, however, no general policy specifically intended by the framers of the fourteenth amendment from which a rule prohibiting segregated education can be derived. The truth, uncomfortable as it may be, is that the language and legislative history of the fourteenth amendment are just as consistent with an understanding that would yield Plessy v. Ferguson ${ }^{254}$ as with an understanding that would produce Brown. ${ }^{255}$ The logic of preemptive lawmaking will not permit a court to pick and choose among competing "background rules," since this would violate the principles of federalism, separation of powers, and electoral accountability, and the Rules of Decision Act. ${ }^{256}$

There is another reason why decisions such as Brown cannot be considered to rest on preemptive lawmaking. If Brown and other modern constitutional decisions were grounded on the perceived necessity of preserving some higher-order policy specifically intended by the framers, then Congress could override these decisions by enacting alternative rules that would provide adequate protection for the policy in question. In other words, Brown would be an example of Monaghan's constitutional common law, not constitutional law proper. Yet no one contends that Brown is subject to congressional override; indeed, according to the Supreme Court, it is the "supreme law of the land" 257 as much as if it were written into the Constitution itself.

It would appear, therefore, that if decisions like Brown are to be justified under the general theory of federal common law, they must be sustained as a form of delegated lawmaking. Of course, there is no provision of the Constitution that expressly authorizes federal courts to develop a body of constitutional rules "in the light of reason and experience." ${ }^{258}$ Thus, nonoriginalist judicial review cannot be considered a form of express delegated lawmaking. The case can be made, however, that a good deal of nonoriginalist review is consistent with the notion of implied delegated lawmak-

${ }^{253}$ Preemptive lawmaking may, however, be combined with delegated lawmaking to reach a result not specifically intended by the framers. See supra note 247.

${ }^{254} 163$ U.S. 537 (1896) (upholding separate-but-equal doctrine).

2ss If this were not the case, then the Brown Court would undoubtedly have invoked the specific intentions of the framers as its ground for rejecting the Plessy approach, which it did not do.

${ }^{258}$ See supra notes 168-74 and accompanying text.

${ }^{267}$ Cooper v. Aaron, 358 U.S. 1, 18 (1958) (dictum).

${ }^{258}$ Cf. FED. R. Evid. 501 (discussed supra note 183 and accompanying text). 
ing. ${ }^{259}$ The principal feature distinguishing implied delegated lawmaking under the Constitution is that the delegation comes directly from the framers. As a consequence, the resulting federal common law rules cannot be overridden by ordinary legislation-only by constitutional amendment.

As noted above, ${ }^{260}$ the doctrine of implied delegated lawmaking requires that two conditions be satisfied before federal common law can be considered legitimate. First, there must be evidence that the enacting body specifically intended to confer lawmaking power on the federal judiciary. Second, the textual source of the delegation must circumscribe, with reasonable specificity, the area in which judicial lawmaking is to take place. The effort to justify nonoriginalist judicial review as implied delegated lawmaking encounters substantial-but not, in my view, ultimately decisive-objections on both scores.

The affirmative case for inferring a specific intent to delegate lawmaking power under the Bill of Rights is fairly similar to the case for inferring such an intention under a statute like section 1 of the Sherman Act. ${ }^{261}$ First, it appears that the framers intended that federal courts would have jurisdiction to enforce provisions of the Constitution such as the Bill of Rights. Article III expressly confers jurisdiction on federal courts in cases "arising under this Constitution," ${ }^{262}$ and the Judiciary Act of 1789, enacted the same year as the first ten amendments, recognized that the Supreme Court could review state court decisions on "the ground of their being repugnant to the constitution."263

Further, an argument for implied delegated lawmaking can be made from the generality of the framers' language. The provisions of the Constitution that give rise to nonoriginalist judicial re-

${ }^{259}$ For earlier (and sketchier) efforts to justify nonoriginalist judicial review as a form of implied delegated lawmaking, see Leonard Levy, Legacy of Suppression 308-09 (1960); Bickel, supra note 252, at 63-64; Karst, supra note 152, at 17; Van Alstyne, The Fourteenth Amendment, the "Right" to Vote, and the Understanding of the Thirty-Ninth Congress, 1965 Sup. CT. REv. 33, 72-73. Professor Monaghan has criticized the delegation theory, Monaghan, supra note 35 , at $361-67$, but his criticism is directed primarily at the notion that provisions such as the due process, equal protection, and privileges and immunities clauses of the fourteenth amendment constitute wholly "open-ended" delegations to federal courts. He approves of the use of the due process and equal protection clauses in ways that are consistent with the theory of implied delegation offered here.

${ }^{280}$ See supra note 182 and accompanying text.

${ }^{281} 15$ U.S.C. $\S 1$ (1982); see supra notes 191-98 and accompanying text.

${ }^{262}$ U.S. Const. art. III, § 2; cf. Marbury v. Madison, 5 U.S. (1 Cranch) 137 (1803) (constitutional provisions judicially enforceable).

${ }^{263}$ Judiciary Act of $1789, \S 25,1$ Stat. 73,85 (current version at 28 U.S.C. $\S 1257$ (1982)) 
view-principally the Bill of Rights and the fourteenth amendment-are drafted in very broad and general terms: "freedom of speech," "unreasonable searches and seizures," "due process of law," "cruel and unusual punishments," and so forth. Because it was intended that this language would be judicially enforced, courts would obviously be required to create a substructure of implementing rules-a body of constitutional doctrine-to translate such general language into a meaningful basis for deciding cases. Of course, the framers themselves, had they wanted to, could have specified the substructure of rules. But there is nothing in the generally sparse legislative history that would suggest that the framers had any specific intentions on this score. ${ }^{264}$ Presumably, therefore, this substructure was to be developed by the courts through the process of case-by-case adjudication.

Finally, many of the provisions of the Bill of Rights have common law origins. The seventh amendment provision concerning appellate review of jury verdicts is expressly couched in terms of "the rules of the common law." ${ }^{285}$ Other amendments are also rooted in the common law. In some instances (for example, the fourth amendment prohibition of general warrants), the provision was first enunciated by English common law courts; ${ }^{266}$ in other instances (for example, the eighth amendment prohibition of cruel and unusual punishments), the source is statutory-the English Bill of Rights - but can nonetheless be considered part of the common law heritage, ${ }^{267}$ in still others (for example, the fifth amendment prohibition of takings without just compensation), the provision was derived from Blackstone's restatement of English common law principles. ${ }^{268}$ The pervasive influence of the common law, broadly defined, suggests that the framers anticipated that federal courts would perform a common law function in giving effect to the constitutional language.

All this does not mean that the case for delegated lawmaking under the Constitution is airtight. Consider, for example, the basic

${ }^{264}$ With the exception of the provisions relating to religious freedom, Congress did little tinkering with the language of the Bill of Rights. See Edward Dumbauld, The Bill of Rights 33-50 (1957) (historical account of textual changes in Bill of Rights). Typically, Congress did little more than vote up or down the draft prepared by Madison. This draft borrowed heavily from proposals submitted by state ratifying conventions, $i d$. at 36 , which in turn drew upon preexisting state constitutional provisions or the English Bill of Rights of 1689 , see id. at 50-56.

${ }^{285}$ U.S. CONST. amend. VII.

${ }^{268}$ Telford Taylor, Two Studies in Constitutional Interpretation 27-44 (1969).

${ }^{267}$ See Raoul Berger, Death Penalties 36-43 (1982).

${ }^{268}$ F. Bosselman, D. Callies \& J. Banta, The Taking Issue ch. 6 (1973). 
question of whether the framers intended to confer jurisdiction on federal courts to enforce the Bill of Rights. As originally envisioned, the Bill of Rights limited the powers of the federal government only, not of the states. ${ }^{268}$ Given the views about sovereign immunity prevailing at the time, ${ }^{270}$ one would think that if Congress intended the first ten amendments to be judicially enforced in direct actions against the federal government, it would have provided for federal court jurisdiction over constitutional claims, amounting to a waiver of federal sovereign immunity. Yet the only mention of constitutional adjudication in the first Judiciary Act concerns review of state court judgments. ${ }^{271}$ It was not until 1875 that Congress conferred general jurisdiction on federal courts to entertain claims arising under the Constitution. ${ }^{272}$

Although the initial absence of general federal-question jurisdiction weakens the claim that Congress intended federal courts to enforce the Bill of Rights, it is not necessarily fatal. Many of the guarantees of the first ten amendments apply to the conduct of trials in federal court, and are thus "self-executing." antees - the first and fourth amendments for example-could have been enforced either through state-law trespass actions against federal officials or as defenses in federal criminal prosecutions. ${ }^{\mathbf{2 7 4}}$

${ }^{269}$ Barron v. Mayor of Baltimore, 32 U.S. (7 Pet.) 243, 247-51 (1833).

${ }^{270}$ As reflected, for example, in the enactment of the eleventh amendment. See also The Federalist No. 81, at 487-88 (A. Hamilton) (C. Rossiter ed. 1961) (inherent in nature of sovereignty not to be amenable to suit without its consent).

271 See supra note 263 and accompanying text.

272 Judiciary Act of 1875,18 Stat. 470 (1875) (codified as amended at 28 U.S.C. $§ 1331$ (1982)).

${ }^{273}$ This would include most of the fifth amendment and all of the sixth, seventh, and eighth amendments.

${ }^{274}$ Since the federal courts have original jurisdiction over federal statutory crimes, and since the free speech clause of the first amendment has typically been raised as a defense in criminal prosecutions, see, e.g., Dennis v. United States, 341 U.S. 494 (1951); Schenck v. United States, 249 U.S. 47 (1919), general federal-question jurisdiction has not played a major role historically in the development of free-speech doctrine. Similarly, fourth amendment issues generally arise in the defense of criminal charges. See, e.g., Weeks v. United States, 232 U.S. 383 (1914). The fourth amendment also has antecedents involving a common law action for trespass brought against intruding government officials. See, e.g., Entick v. Carrington, 95 Eng. Rep. 807 (C.P. 1765). This method of enforcing the fourth amendment was urged by the government in Bivens v. Six Unknown Named Agents of Fed. Bureau of Narcotics:

In [the government's proposed] scheme the Fourth Amendment would serve merely to limit the extent to which the agents could defend the state law tort suit by asserting that their actions were a valid exercise of federal power: if the agents were shown to have violated the Fourth Amendment, such a defense would be lost to them and they would stand before the state law merely as private individuals.

403 U.S. 388, 390-91 (1971). 
Thus, a large part of the Bill of Rights allows room for federal common lawmaking even without a general grant of federal-question jurisdiction. ${ }^{275}$ Furthermore, there is at least one statement in the recorded debates on the enactment of the first ten amendments that suggests that the framers anticipated judicial enforcement of the Bill of Rights. ${ }^{276}$ This statement refers only to "independent tribunals of justice"-which could mean both state and federal courts. I would conclude, therefore, that it is entirely possible that the framers intended federal judicial enforcement of the Bill of Rights, but in the case of those provisions that were not "self-executing," enforcement would be achieved principally through Supreme Court review of state-court judgments.

Another vexing question is whether the framers, in adopting common law precepts in the Bill of Rights, intended to federalize an evolving body of common law or simply to freeze an existing body of common law. ${ }^{277}$ Indeed, since common law courts were widely thought in 1789 to "discover" rather than to "make" common law, ${ }^{278}$ it can be argued that it is unlikely that the framers contemplated that federal courts would play an active "lawmaking" role in interpreting the Bill of Rights.

275 This still does not fully account for those provisions, such as the religion and speech clauses of the first amendment and the just compensation clause of the fifth amendment, that directly constrain the behavior of Congress. Indeed, the just compensation clause did not become judicially enforceable until 1887 with the enactment of the Tucker Act, 24 Stat. 505 (1887) (current version at 28 U.S.C. $§ 1491(\mathrm{a})(1)$ (1982)); see HART \& Wechsler, supra note 17 , at $98-100$.

${ }^{276}$ Madison stated to the House:

It has been said that it is unnecessary to load the Constitution with this provision, because it was not found effectual in the constitution [sic] of the particular States. It is true, there are few particular States in which some of the most valuable articles have not, at one time or other, been violated; but it does not follow but they may have, to a certain degree, a salutary effect against the abuse of power. If they are incorporated into the Constitution, independent tribunals of justice will consider themselves in a peculiar manner the guardians of those rights; they will be an impenetrable bulwark against every assumption of power in the Legislative or Executive; they will be naturally led to resist every encroachment upon rights expressly stipulated for in the Constitution by the declaration of rights.

1 Annals of Cong. 439 (1789). In his efforts to persuade Madison to support the idea of a Bill of Rights, Jefferson listed among the benefits "one which has great weight with me, the legal check which it puts into the hands of the judiciary. This is a body, which if rendered independent \& kept strictly to their own department merits great confidence for their learning \& integrity." Letter from Thomas Jefferson to James Madison (Mar. 15, 1789), quoted in E. Dumbauld, supra note 264 , at 9.

${ }^{277}$ See R. Berger, supra note 267, ch. 4 (framers intended to "freeze" the common law of cruel and unusual punishments as of the time the eighth amendment was adopted).

278 Morton Horwitz, The Transformation of American Law 4-9 (1977); Hill, supra note 23 , at 1069 . 
Again, however, this objection is not necessarily dispositive. Even if it is correct that most of the framers thought of common law courts as oracles "discovering" the law, ${ }^{279}$ one could still find an intent to delegate. So long as the framers were reasonably clear in their understanding that the courts-rather than Congress or the Executive or the framers themselves-would supply meaning to the "broad and majestic terms" haps the intent to delegate may be appropriately inferred. In other words, the key question would seem to be which institution the framers expected would interpret the generalities of the Bill of Rights, not how the framers assumed that institution would behave in carrying out this role. Thus, so long as the framers expected the courts to fashion a substructure of rules under the broad language of the Bill of Rights, it does not really matter whether they thought the courts would "discover" these rules by looking to immutable truths, or "create" these rules in accordance with their own conception of constitutional purposes.

In any event, the doubts that can be entertained about the intentions of the generation of 1789 cannot be extended to the draftsmen of the fourteenth amendment. By 1868, every constitutional lawyer was familiar with the Supreme Court's practice of creating a substructure of constitutional rules under general provisions similar to the Bill of Rights-the contract clause is a prime example ${ }^{281}$-in ways that were not specifically intended by the framers. ${ }^{282}$ By adopting the same kind of general constitutional language as had been used in the original Constitution, the framers of the fourteenth amendment can be presumed to have intended

279 It is not entirely clear that the conceit about common law judges "discovering" the common law was ever much more than just that-a conceit. Even Blackstone, who is prominently identified with the "oracular" view, recognized at the same time that judges employ fictions to nullify laws they do not like. See 2 William Blackstone, Commentaries *116-17. I suspect that Professor Louis Lusky may be right in saying that, although the framers "were steeped in the Blackstonian tradition that courts discover the law and do not make it[,]. . . a careful cross-examiner could have extracted an admission" that courts make law. Louis Lusky, By What Right? 61 (1975); see also Arnold, Statutes as Judgments: The Natural Law Theory of Parliamentary Activity in Medieval England, 126 U. PA. L. REv. 329, 342-43 (1977) (natural law tradition weak in England; medieval jurists viewed statutes as changing the law rather than as reflecting immutable truths).

280 Board of Regents v. Roth, 408 U.S. 564, 571 (1972).

281 See generally Benjamin Wright, The Contract Clause of the Constitution 27-88 (1938) (discussing expansion of the scope of the contract clause under Marshall and Taney Courts).

${ }^{282}$ See J. Ely, supra note 9, at 40-41 (consensus after the Civil War favored judicial review); Bickel, supra note 252, at 59 (tradition of "broadly worded organic law" well-established by 1866). 
that federal courts would perform a similar "common law" function in giving effect to section 1 of that amendment. ${ }^{283}$

Finding an implicit intent to delegate, however, is only the first step in the analysis: it is also necessary to find that the framers circumscribed the area of delegation with reasonable specificity. ${ }^{284}$ The delegation of lawmaking power to federal courts can be squared with the principles of federalism, separation of powers, and electoral accountability, and with the Rules of Decision Act only if the ratifiers were given adequate notice of the scope of lawmaking power being transferred to federal courts. To what extent can it be said that the provisions of the Bill of Rights and the fourteenth amendment provide this kind of notice? The answer would appear to vary depending on the provision in question.

At one extreme, some of the provisions cannot be said to provide any kind of notice of their scope. The ninth amendment falls within this category, as does the privileges and immunities clause of the fourteenth amendment (unless one accepts the argument that it was intended to constitutionalize the list of fundamental rights set forth in Corfield v. Coryell, ${ }^{285}$ or was intended to make the first eight amendments applicable against the states $\left.{ }^{286}\right)$. For the most part, the Supreme Court has considered these provisions to be too general to be enforced and has refused to rely on them as a basis for judicial lawmaking. ${ }^{287}$

${ }^{283}$ It has been suggested that section 5 of the fourteenth amendment, which grants to Congress the power to enforce the amendment, gives rise to the negative implication that federal courts were not to have such enforcement powers. See R. BERGER, supra note 9, ch. 12. But given the long and highly visible tradition of federal judicial enforcement of other constitutional provisions directed against the states, see B. WRIGHT, supra note 381 (contract clause cases), I find it implausible that the framers of 1868 would have assumed that some special mention of federal judicial enforcement was required or that a positive grant to Congress was sufficiently explicit to negative the tradition of judicial enforcement. On the other hand, given the restrictive view of Congress's powers under the commerce clause then current, the framers could easily have thought that a special grant of power to Congress was needed in order to assure the constitutionality of the Civil Rights Act and other implementing legislation.

${ }^{284}$ See supra note 182 and accompanying text.

${ }^{285} 6$ F. Cas. 546, 551-52 (C.C.E.D. Pa. 1823) (No. 3230) (Washington, J.) (listing various privileges and immunities "which are, in their nature, fundamental"). Professor Raoul Berger in effect makes such an argument. See R. BERgER, supra note 9, ch. 2.

${ }^{286}$ This was Justice Black's view. See Duncan v. Louisiana, 391 U.S. 145, 166 (1968) (Black, J., concurring); Adamson v. California, 332 U.S. 46, 71-75 (1947) (Black, J., dissenting). The argument supporting the framers' intention to incorporate the Bill of Rights into the fourteenth amendment may be stronger than is generally assumed. See J. ELY, supra note 9 , at 24-27 and especially n.59.

${ }^{287}$ See, e.g., The Slaughterhouse Cases, 83 U.S. (16 Wall.) 36 (1873) (severely narrowing scope of privileges and immunities clause of the fourteenth amendment); cf. Griswold v. Connecticut, 381 U.S. 479, 520 (Black, J., dissenting) (ninth amendment was intended to 
At the other extreme, a provision like the free speech clause does seem to delineate an area of lawmaking with enough specificity to sustain the delegation of power to federal courts. Of course, if those who ratified the amendment were brought back to life and asked whether the free speech clause was intended to extend constitutional protection to pornography and commercial advertising, they would probably say "no." But the relevant question is not whether the ratifiers would have recognized these things as constitutionally protected speech. Rather, it is whether they would have recognized pornography and commercial advertising as forms of "speech." To this question, I would imagine that the answer would be "yes." Thus, even though the ratifiers might be surprised or even shocked by the results of modern free speech cases, they would probably not find that the issues being considered by the modern Supreme Court fall outside the compass of the constitutional provision. If I am correct about this, then the delineation of lawmaking power by the free speech clause is sufficiently precise to sustain the delegation of power to federal courts.

Between the extremes of the ninth amendment and the first amendment there are more problematic provisions-in particular, the due process and equal protection clauses. The due process clauses of the fifth and fourteenth amendments are difficult to construe today because the language suggests that the framers were only concerned with procedural issues-the "due" or fair process that must be afforded before persons are deprived of life, liberty, or property. ${ }^{288}$ So taken, these clauses might be thought to frame an area of delegated power with enough specificity to justify lawmaking by federal courts. But if, as the Supreme Court has held without ever completely reversing itself, the clauses are thought to impose a substantive constraint on federal and state legislation, ${ }^{288}$ it is hard to see how the text and history provide meaningful speci-

limit, not broaden, powers of federal government). John Hart Ely argues that the privileges and immunities clause and the ninth amendment should be construed as open-ended delegations to courts. See J. Ely, supra note 9, at 22-30, 34-41. But even if he is right about the framers' intent to delegate under these provisions (and, at least in the case of the ninth amendment, I do not believe he is right), there is still the question whether such an unconstrained delegation would satisfy the internal norm of legitimacy. Unless the provisions gave the ratifiers a reasonably clear idea of what powers they were giving to the courts, federal courts should not accept the proffered delegation.

${ }^{288}$ See J. Ely, supra note 9, at 14-21 ("substantive due process" a contradiction in terms); Monaghan, supra note 35, at 364 (original intent limits due process clauses to concern for "fair adjudicatory procedures").

${ }^{288}$ See, e.g., Lochner v. New York, 198 U.S. 45, 53 (1905); Roe v. Wade, 410 U.S. 113, 153 (1973). 
ficity for the sorts of issues that the federal courts are to review. A similar point can be made about the equal protection clause. If the clause is read in conjunction with its history as an expression of concern about unequal treatment of the races (and, perhaps, closely analogous problems ${ }^{280}$ ), then perhaps it provides enough specificity to satisfy the internal norm of legitimacy. But if the clause is taken as a warrant for generalized review of the "rationality" of legislative classifications, ${ }^{291}$ then it is difficult to see how those voting to ratify the clause could have had any notion of the sorts of questions that might be entertained by the courts.

As is well known, the Supreme Court has sporadically attempted to curb the excesses of "substantive due process" and "fundamental rights" equal protection, ${ }^{292}$ but it has refused to abandon all reliance on these concepts. Particularly persistent instances may be found in cases declaring "procreational and family rights," ${ }^{293}$ founded on substantive due process, and reapportionment and voting rights, ${ }^{294}$ founded on the fundamental-rights branch of equal protection. Under the doctrine of delegated lawmaking, these forms of constitutional lawmaking must be regarded as illegitimate. Of course, these particular lines of cases have long been regarded as suspect by constitutional scholars. But they are not suspect, as some have suggested, ${ }^{295}$ because they lack support in the specific intentions of the framers-if that were true, very little constitutional law could be sustained. Rather, they are suspect because they are grounded in constitutional provisions that provide no notice that they might be used as a foundation for judicial lawmaking with respect to these sorts of issues.

Obviously, the foregoing constitutes the barest sketch of how the doctrine of delegated lawmaking might be applied to assess the legitimacy of nonoriginalist judicial review. One final point is in

290 See, e.g., Graham v. Richardson, 403 U.S. 365 (1971) (alienage); Hernandez v. Texas, 347 U.S. 475 (1954) (nationality); see generally Monaghan, supra note 35, at 364-65 (equal protection clause may be applicable to discrimination "closely analogous to racial discrimination").

${ }^{291}$ See, e.g., Zobel v. Williams, 457 U.S. 55, 60 (1982).

292 See, e.g., United States R.R. Retirement Bd. v. Fritz, 449 U.S. 166 (1980) (equal protection); Williamson v. Lee Optical Co., 348 U.S. 483 (1955) (due process).

${ }^{293}$ See, e.g., Moore v. City of East Cleveland, 431 U.S. 494, 499 (1977) (plurality opinion) (right of relatives to live together); Roe v. Wade, 410 U.S. 113, 153 (1973) (right to abortion).

${ }^{294}$ See, e.g., Reynolds v. Sims, 377 U.S. 533, 561-62 (1964) (right to vote a "fundamental matter").

${ }^{295}$ See, e.g., id. at 595 (Harlan, J., dissenting) (reapportionment decisions inconsistent with original intent of draftsmen of the fourteenth amendment); R. BERGER, supra note 9, ch. 5 (same). 
order, however, before concluding. At the risk of oversimplification, the controversy over the legitimacy of nonoriginalist judicial review can be seen as a debate between what can be called the "originalist" camp ${ }^{296}$ on the one hand and the "fundamental moral values" camp $^{287}$ on the other. The first group maintains that constitutional lawmaking is legitimate only insofar as it coincides with a preconstitutional norm consisting of the specific intentions of the framers. The second maintains that constitutional lawmaking is legitimate only insofar as it rests on a preconstitutional norm consisting of certain "correct" fundamental moral values. In either view, judicial precedent-the most important tool of the constitutional lawyer-drops from sight. Instead, we are presented with the picture of constitutional adjudication as a process of abstract ratiocination wherein specific conclusions are deduced from competing sets of preconstitutional norms. Decades of precedent that intervene between the enactment of the constitutional provision and the decision-or that cloud the clarity of the fundamental moral principles assertedly embodied in the norm-are then either ignored or dismissed in favor of a return to first principles. ${ }^{298}$

In reality, of course, a constitutional lawyer does not start with an analysis of the specific intentions of the framers or with a conception of certain "correct" moral values. The lawyer starts with the case law ${ }^{298}$ and reasons by analogy from the case law. Only when these sources fail him does he turn to evidence of the framers' intentions or to moral argument. Under the doctrine of delegated lawmaking, precedent is restored to its rightful place at the

${ }^{298}$ E.g., R. BERGER, supra note 9; Bork, supra note 151; Monaghan, supra note 35.

${ }^{297}$ E.g., M. PERRY, supra note 9; Dworkin, supra note 15; Richards, supra note 43. Needless to say, there is substantial variation in the positions of these (and other) authors regarding the source and content of the fundamental moral values in question.

${ }^{298}$ Others have made a similar observation about contemporary constitutional theorists. See, e.g., Bennett, Objectivity in Constitutional Law, 132 U. PA. L. REv. 445, 480-89 (1984); Michelman, Constancy to an Ideal Object, 56 N.Y.U. L. REv. 406, 406 (1981); Monaghan, supra note 35, at 390-91; see also Levinson, supra note 41, at 379 n.19 ("Perhaps the central difference between law and literature is the lack in the latter of the notion of stare decisis.").

${ }^{299}$ The "common law" nature of constitutional adjudication has been widely remarked upon. See, e.g., Glennon, Constitutional Liberty and Property: Federal Common Law and Section 1983, 51 So. CaL. L. REv. 355, 382 (1978); Jones, The Brooding Omnipresence of Constitutional Law, 4 VT. L. Rev. 1, 27, 28 (1979); Posner, Statutory Interpretation-in the Classroom and in the Courtroom, 50 U. CHI. L. Rev. 800, 808 (1983). Even Professor Monaghan, who believes that constitutional law (as opposed to constitutional common law) should rest on a search for the specific intentions of the framers, is forced to concede the point. See Monaghan, supra note 35, at 393 (common law approach best describes development of constitutional law under Bill of Rights). 
center of the constitutional lawyer's universe. Indeed, if we start with the assumption that the framers delegated power to the federal courts to create a federal common law of constitutional rights, then the the body of precedent painstakingly created by the Supreme Court over the years is the "Bill of Rights." Thus, the doctrine of delegated lawmaking not only serves to reconcile judicial lawmaking under the Bill of Rights with the internal norm of legitimacy, but it also provides a more accurate description of the nature of constitutional adjudication than do the principal theories of legitimacy advanced by modern constitutional scholars.

\section{ConcLusion}

The foregoing survey suggests that, at least outside the area of constitutional lawmaking, application of the general theory of federal common law would not require a radical change in our understanding of the common law powers of federal courts. Some of the most important benchmarks in Supreme Court doctrine-such as the early rejection of federal common law crimes, Erie's denial of general lawmaking power on the part of federal courts in diversity cases, and the modern Court's disavowal of any inherent power to create implied rights of action or contribution-are consistent with the theory. Furthermore, even where doctrines enunciated by the Court deviate from the general theory, the final decision on whether to adopt federal common law is nevertheless usually consistent with what the general theory would dictate.

With respect to constitutional lawmaking, however, it is less clear that the Court's practice can be reconciled with the general theory. Often, as in the case of the wide-ranging jurisprudence of substantive due process and fundamental-rights equal protection, the Court seems to assert greater lawmaking powers than would be authorized if constitutional lawmaking were viewed as a species of federal common law. The fact that the Court has treated implied statutory remedies differently from Bivens actions is another example of the assertion of broader judicial power in constitutional cases (although the differences here may be narrowing ${ }^{300}$ ). Yet it would be surprising to find that the internal norm of legitimacy has not had at least a conditioning influence on constitutional lawmaking. The principles of federalism, separation of powers, and

${ }^{300}$ In Davis v. Passman, 442 U.S. 228, 240-43 (1979), the Court stated that federal courts have broader remedial powers in constitutional cases, but a more recent decision suggests that the Court may be moving toward convergence in this area. See Bush v. Lucas, 103 S. Ct. 2404 (1983) (discussed supra note 209). 
electoral accountability are so deeply ingrained in our constitutional system-so fundamental to our way of thinking about the appropriate allocation of lawmaking power-that one would expect to find evidence of their influence at work even if they were never cited as a basis for decision.

Indeed, my survey of implied remedies, constitutional common law, and nonoriginalist judicial review reveals at least some evidence of the influence of the internal norm of legitimacy on constitutional lawmaking. Perhaps the most significant is the fact that some federal common law that derives its authority from the Constitution-in particular Bivens actions and constitutional common law-is subject to reversal by Congress, whereas other federal common law based on the Constitution-such as nonoriginalist judicial review-is not. The general theory, through the derivative doctrines of preemptive and delegated lawmaking, can account for this phenomenon. Other ordering principles have greater difficulty in doing so. ${ }^{301}$ Other aspects of constitutional lawmaking are also consistent with the influence of the internal norm of legitimacy. For example, both the Court's reluctance to consider open-ended provisions (such as the ninth amendment) justiciable and the dominant role of judicial precedent in the development of the meaning of broad constitutional provisions are consistent with constitutional lawmaking viewed as a species of federal common law subject to the internal norm. Admittedly, these features of constitutional lawmaking do not amount to conclusive evidence that the Court has been, perhaps unwittingly, applying the general theory in these areas. But they provide some support for the notion that the internal norm has had a conditioning effect, even where its relevance has not been expressly acknowledged.

Whether or not one concludes that the internal norm of legitimacy has conditioned constitutional lawmaking, how much difference would it make if all federal common law were expressly acknowledged to be subject to the norm? Admittedly, in some cases it would not make much difference. If, for example, one believes that the principal challenge presented by nonoriginalist judicial review is the lack of any "objective" basis for judicial decisionmaking other than judicial precedent and the judges' own conceptions of

${ }^{301}$ For example, Schrock and Welsh, proceeding from originalist premises, assert that judicial interpretation of the Constitution must be narrow and final and that constitutional common law subject to congressional override is illegitimate. Schrock \& Welsh, supra note 39 , at $1174-76$. 
constitutional purpose ${ }^{302}$ then viewing nonoriginalist review as a form of federal common law provides little solace. To be sure, the concept of delegated lawmaking provides a foundation for understanding the importance of precedent in the development of nonoriginalist review, but it does not get around the fact that largely unguided normative judgments will have to be made by judges in the development of this precedent. Thus, if one believes that there must be an "objective" (or "correct") moral foundation for constitutional decisionmaking, the quest for this foundation will not be appreciably advanced by conceptualizing nonoriginalist review as a form of federal common law.

Still, I think that there are major benefits to be gained from viewing all federal judicial lawmaking, including nonoriginalist review, as forms of federal common law. Perhaps the most obvious is that, if one agrees that the internal norm of legitimacy is the ultimate ordering principle behind the general structure of the system of federal common law, then by making that norm express and applying it to all forms of federal common lawmaking, the internal coherence and consistency of judicial performance in this area should be considerably enhanced. Moreover, even if one concludes that the internal norm is not currently applied in all areas, there would be certain gains (besides the obvious advantage of parsimony) from making it the universal standard for assessing the legitimacy of federal judicial lawmaking. Application of the general theory would yield more specific answers to hard questions that are currently dealt with through vague discussions about whether federal "interests" or "values" require a federal rule of decision. In this way, the theory would promote rigor and clarity in judicial thinking about the appropriate role of federal common law in what remains a system of federated and separated powers. Further, application of the general theory would provide a structure for deciding questions of federal common law and a method of relating those questions back to principles that are widely, if not universally, regarded as important. Thus, it might bring some predictability and stability to issues regarding the permissible scope of federal judicial lawmaking. These qualities are always scarce, but in this field they seem to be in especially short supply.

${ }^{302}$ See, e.g., Bennett, supra note 298 , at 445-46. 